\title{
Review \\ Berberine, a Herbal Metabolite in the Metabolic Syndrome: The Risk Factors, Course, and Consequences of the Disease
}

\author{
Anna Och ${ }^{1, *}$, Marek Och ${ }^{2}$, Renata Nowak ${ }^{1}$, Dominika Podgórska ${ }^{3}$ and Rafał Podgórski ${ }^{4}$ \\ 1 Chair and Department of Pharmaceutical Botany, Medical University of Lublin, 1 Chodźki St., \\ 20-093 Lublin, Poland; renatanowak@umlub.pl \\ 2 Parexel Poland Sp. z o.o., ul. Żwirki i Wigury 18a, 02-092 Warsaw, Poland; marek.och@parexel.com \\ 3 Department of Internal Diseases, Institute of Medical Sciences, Medical College of Rzeszow University, \\ 35-959 Rzeszow, Poland; dpodgorska@ur.edu.pl \\ 4 Department of Biochemistry, Institute of Medical Sciences, Medical College of Rzeszow University, \\ 35-959 Rzeszow, Poland; rpodgorski@ur.edu.pl \\ * Correspondence: anna.och@umlub.pl
}

check for updates

Citation: Och, A.; Och, M.; Nowak, R.; Podgórska, D.; Podgórski, R. Berberine, a Herbal Metabolite in the Metabolic Syndrome: The Risk Factors, Course, and Consequences of the Disease. Molecules 2022, 27, 1351. https://doi.org/10.3390/ molecules27041351

Academic Editors: John C. D'Auria and Enrique Barrajon

Received: 8 November 2021

Accepted: 13 February 2022

Published: 17 February 2022

Publisher's Note: MDPI stays neutral with regard to jurisdictional claims in published maps and institutional affiliations.

Copyright: (c) 2022 by the authors. Licensee MDPI, Basel, Switzerland. This article is an open access article distributed under the terms and conditions of the Creative Commons Attribution (CC BY) license (https:// creativecommons.org/licenses/by/ $4.0 /)$.

\begin{abstract}
In recent years, the health of patients exposed to the consequences of the metabolic syndrome still requires the search for new solutions, and plant nutraceuticals are currently being intensively investigated. Berberine is a plant alkaloid possessing scientifically determined mechanisms of the prevention of the development of atherosclerosis, type 2 diabetes, and obesity, as well as cardiovascular complications and cancer. It positively contributes to elevated levels of fasting, postprandial blood glucose, and glycosylated hemoglobin, while decreasing insulin resistance. It stimulates glycolysis, improving insulin secretion, and inhibits gluconeogenesis and adipogenesis in the liver; by reducing insulin resistance, berberine also improves ovulation. The anti-obesity action of berberine has been also well-documented. Berberine acts as an anti-sclerotic, lowering the LDL and testosterone levels. The alkaloid exhibits an anti-inflammatory property by stalling the expression of cyclooxygenase 2 (COX-2) and prostaglandin E2. Berberine is neuroprotective and acts as an antidepressive. However, the outcomes in psychiatric patients are nonspecific, as it has been shown that berberine improves metabolic parameters in schizophrenic patients, acting as an adjuvant during antipsychotic treatment. Berberine acts as an anticancer option by inducing apoptosis, the cell cycle arrest, influencing MAPK (mitogen-activated protein kinase), and influencing transcription regulation. The inhibition of carcinogenesis is also combined with lipid metabolism.
\end{abstract}

Keywords: berberine; metabolic syndrome; cancer; cancer prevention; obesity; type 2 diabetes mellitus; ischemic heart disease; stroke; myocardial infarction; atherosclerosis; polycystic ovary syndrome; clinical trials

\section{Introduction}

The metabolic syndrome, also called syndrome $X$, is a set of interrelated factors that significantly increase the risk of developing atherosclerosis and type 2 diabetes (T2DM) and, consequently, cardiovascular disorders [1]. The risk of developing the metabolic syndrome, and its course severity, can be reduced by eliminating risk factors, such as an inappropriate diet, physical inactivity, stress, anxiety-depressive disorders, personality disorders, and the resulting behavioral addictions (Figure 1).

The fight against this complex disease also involves the treatment of identified disorders within the metabolic syndrome, such as atherogenic dyslipidemia (hypertriglyceridemia and lowering LDL cholesterol), as well as the treatment of the repercussions of the metabolic syndrome, such as atherosclerosis, diabetic feet, liver cirrhosis due to non-alcoholic or alcoholic steatohepatitis, acute or chronic pancreatitis, local or general immunodeficiencies, and tendency for recurrent infections [2-4]. A consequence of the metabolic syndrome is an increased risk of some malignant neoplasms. In the course 
of the metabolic syndrome, disorders of menstruation, ovulation, and fertility can also be observed, as well as miscarriages and those resulting from cerebral microcirculation disturbances, such as psychoorganic and mood disorders $[5,6]$.

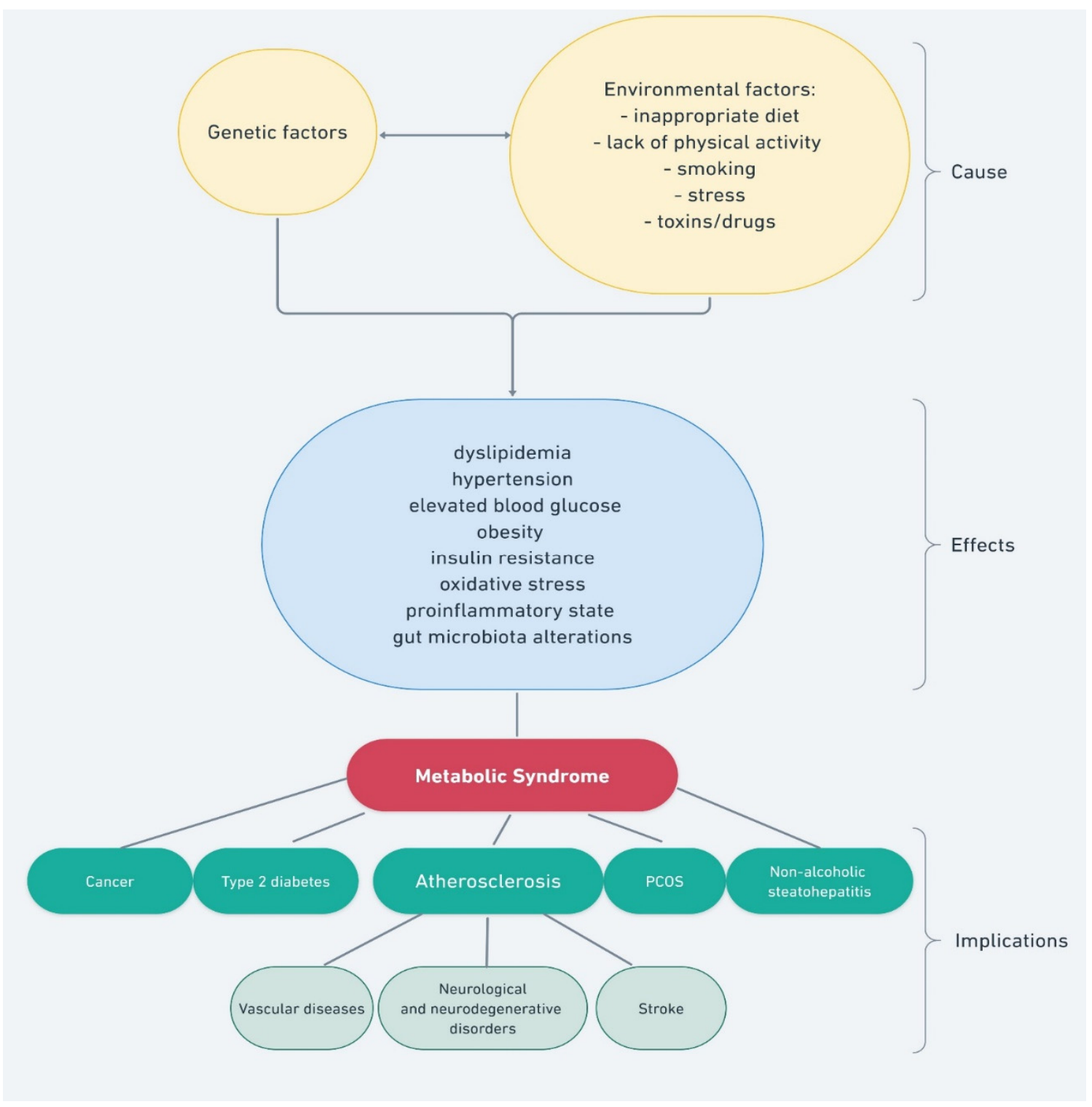

Figure 1. Factors and processes that impact the development of the metabolic syndrome.

Berberine is an alkaloid with strong pharmacological activities that are currently receiving great interest. Berberine has always been used in traditional medicine as a plant extract, but new research methods have established that berberine is a promising treatment for current diseases. A recent study has confirmed the significance of its anticancer activity and its effectiveness in neurological, metabolic, and cardiovascular disorders. The compound has been subjected to multiple clinical evaluations in patients with the metabolic syndrome, and its use in related diseases (Table 1) [7]. The graphic summary of the potential action of berberine in the risk, course, and consequences of the metabolic syndrome is presented in Figure 2. 


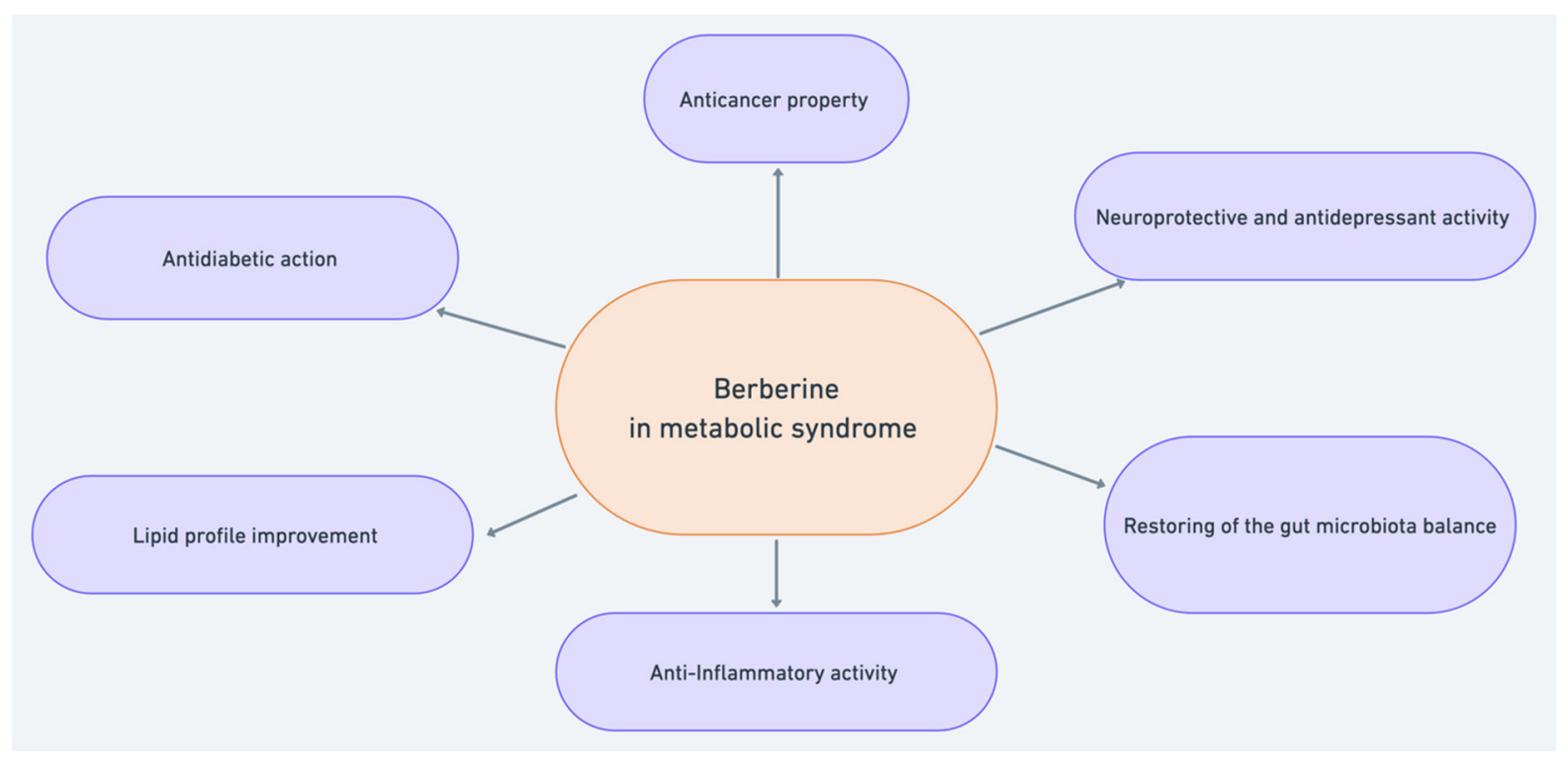

Figure 2. Potential berberine activity against the metabolic syndrome.

The authors searched the following databases: PubMed, Scopus, Springer, Taylor \& Francis Online, and Google Scholar using the keywords: berberine and: metabolic syndrome, inflammation, cholesterol level disorders, obesity, diabetes mellitus, depression, mental disorders, cardiovascular diseases in recent 30 years. A review of more than 2000 studies on the metabolic syndrome and the biological activities of berberine, and its in vitro and in vivo properties, was carried out, and 173 manuscripts were selected regarding the description of the actions and the potential use of the alkaloid in patients at risk of a sequelae of syndrome $X$ disorders. 
Table 1. Completed clinical trials with berberine in the metabolic syndrome based on clinicaltrials.gov (accessed on 10 Fabruary 2022).

\begin{tabular}{|c|c|c|c|c|c|c|c|}
\hline Title & Conditions & Phase & Subjects & Duration & $\begin{array}{l}\text { Interventions } \\
\text { Given }\end{array}$ & Measures & $\begin{array}{c}\text { Results in Berberine or } \\
\text { Nutraceutical } \\
\text { Combination Groups }\end{array}$ \\
\hline $\begin{array}{c}\text { A Mechanistic } \\
\text { Randomized Controlled } \\
\text { Trial on the } \\
\text { Cardiovascular Effect of } \\
\text { Berberine }\end{array}$ & $\begin{array}{l}\text { Cardiovascular } \\
\text { risk factor }\end{array}$ & $\begin{array}{l}\text { Phase } 2 \\
\text { Phase } 3\end{array}$ & $\begin{array}{l}84 \text { men of Chinese ethnicity aged } 20 \\
\text { to } 65 \text { years with hyperlipidemia, not } \\
\text { currently receiving hormone } \\
\text { replacement therapy such as } \\
\text { testosterone replacement therapy in } \\
\text { the past } 12 \text { months; not currently } \\
\text { taking berberine or traditional } \\
\text { Chinese medicine that contains } \\
\text { berberine in the past } 1 \text { month; free of } \\
\text { congenital diseases, infectious } \\
\text { diseases, anemia, and } \\
\text { glucose-6-phosphate dehydrogenase } \\
\text { deficiency; and no history of any } \\
\text { chronic diseases. including ischemic } \\
\text { heart disease, myocardial infarction } \\
\text { (heart attack), stroke, diabetes, } \\
\text { cancer, liver/renal dysfunction, and } \\
\text { gastrointestinal disorders }\end{array}$ & 12 weeks & $\begin{array}{l}\text { Berberine verus } \\
\text { placebo }\end{array}$ & 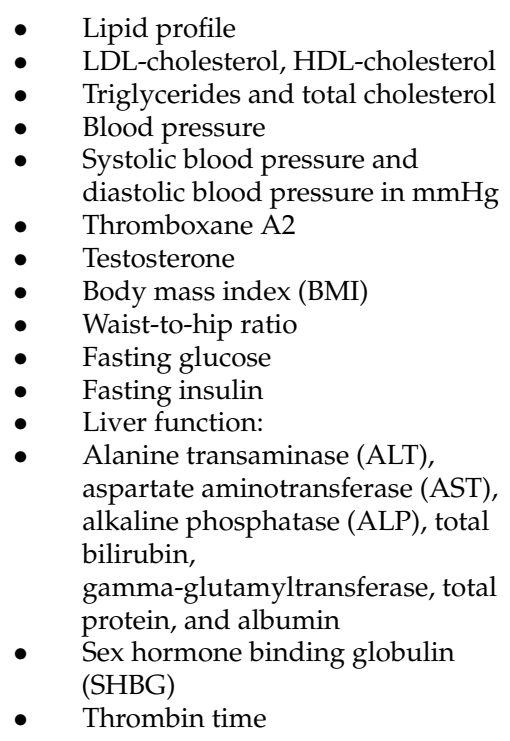 & $\begin{array}{ll}\text { - } & \text { Reduction in total } \\
\text { cholesterol and } \\
\text { - } & \text { BDL-C } \\
& \text { werberine was safe } \\
\text { with no serious } & \text { adverse events } \\
\text { - } \quad \text { Reduction in LDL-C } \\
\text { Increase in } \\
\text { testosterone in males } \\
\text { No differences in } \\
\text { triglycerides, } \\
\text { thromboxane A2, } \\
\text { blood pressure, BMI, } \\
\text { or waist-to-hip } \\
\text { ratio [8] }\end{array}$ \\
\hline $\begin{array}{l}\text { Long-term efficacy and } \\
\text { tolerability of a } \\
\text { nutraceutical } \\
\text { combination (red yeast } \\
\text { rice, policosanols, and } \\
\text { berberine (MBP-NC)) in } \\
\text { patients with } \\
\text { low-moderate risk of } \\
\text { hypercholesterolemia: a } \\
\text { double-blind, } \\
\text { placebo-controlled } \\
\text { Study of the }\end{array}$ & $\begin{array}{l}\text { Hyperchol- } \\
\text { esterolemia }\end{array}$ & Phase 4 & $\begin{array}{l}60 \text { adults between } 18 \text { and } 60 \text { years } \\
\text { with newly diagnosed primary } \\
\text { hypercholesterolemia, not } \\
\text { previously treated, after a run-in } \\
\text { period of } 3 \text { weeks on a stable } \\
\text { hypolipidic diet, with a body mass } \\
\text { index between } 18,5 \text { ad } 29,9 \mathrm{Kg} / \mathrm{m}^{2}, \\
\text { serum low-density lipoprotein } \\
\text { cholesterol above } 150 \mathrm{mg} / \mathrm{dL} \text {, and } \\
\text { an estimated } 10 \text {-year cardiovascular } \\
\text { risk of }<20 \% \text { according to the } \\
\text { Framingham risk scoring }\end{array}$ & $\begin{array}{c}\text { Assessement } \\
\text { after } 4,12 \text { and } \\
24 \text { weeks of } \\
\text { treatment. }\end{array}$ & $\begin{array}{c}\text { Nutraceutical } \\
\text { combination of red } \\
\text { yeast rice extract } \\
\text { (monacolins), } \\
\text { berberine, and } \\
\text { policosanols after } \\
\text { dinner, in addition } \\
\text { to the hypolipidic } \\
\text { diet versus placebo }\end{array}$ & $\begin{array}{ll}-\quad & \text { Level of cholesterol } \\
-\quad & \text { Level of tryglicerides }\end{array}$ & 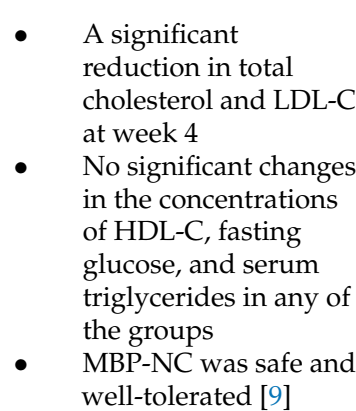 \\
\hline
\end{tabular}


Table 1. Cont.

\begin{tabular}{|c|c|c|c|c|c|c|c|}
\hline Title & Conditions & Phase & Subjects & Duration & $\begin{array}{l}\text { Interventions } \\
\text { Given }\end{array}$ & Measures & $\begin{array}{c}\text { Results in Berberine or } \\
\text { Nutraceutical } \\
\text { Combination Groups }\end{array}$ \\
\hline $\begin{array}{l}\text { effects of Armolipid } \\
\text { Plus on cholesterol } \\
\text { levels and endothelial } \\
\text { function } \\
\text { (mixture of berberine, } \\
\text { policosanol, and red } \\
\text { yeast) }\end{array}$ & $\begin{array}{l}\text { Hyperlipidemia } \\
\text { Endothelial } \\
\text { dysfunction }\end{array}$ & $\begin{array}{c}\text { Not } \\
\text { Applicable }\end{array}$ & $\begin{array}{c}50 \text { adults aged between } 18 \text { and } 70 \\
\text { with total cholesterol levels } \\
>220 \mathrm{mg} / \mathrm{dL} \text {; LDL-cholesterol } \\
>130 \mathrm{mg} / \mathrm{dL} \text {; and with concomitant } \\
\text { pathology, such as diabetes, chronic } \\
\text { heart failure, coronary artery disease, } \\
\text { arterial hypertension, and } \\
\text { dysthyroidism, if stable in the } \\
\text { previous three months }\end{array}$ & 6 weeks & $\begin{array}{c}\text { Mixture of } \\
\text { berberine, } \\
\text { policosanol, red } \\
\text { yeast versus } \\
\text { placebo }\end{array}$ & $\begin{array}{l}\text { - Percentage change from baseline of } \\
\text { total cholesterol, LDL-cholesterol } \\
\text { (LDL-C), HDL-cholesterol (HDL-C) } \\
\text { and Triglycerides (Tg) plasma } \\
\text { concentrations } \\
\text { - Improvement of endothelial } \\
\text { dysfunction }\end{array}$ & $\begin{array}{ll}\text { - } & \text { Significant reduction } \\
\text { in the homeostasis } \\
\text { model assessment of } \\
\text { insulin resistance } \\
\text { (HOMA-IR index) } \\
\text { Significant decrease in } \\
\text { total and low-density } \\
\text { lipoprotein cholesterol } \\
\text { Triglycerides, high } \\
\text { density lipoprotein } \\
\text { cholesterol, and oral } \\
\text { glucose tolerance test } \\
\text { (OGTT) were not } \\
\text { affected } \\
\text { Significant reductions } \\
\text { in blood glucose and } \\
\text { insulin after the } \\
\text { standard mixed meal } \\
\text { Increase in } \\
\text { flow-mediated } \\
\text { dilation (FMD) and a } \\
\text { significant reduction } \\
\text { in arterial systolic } \\
\text { blood pressure [10] }\end{array}$ \\
\hline
\end{tabular}


Table 1. Cont.

\begin{tabular}{|c|c|c|c|c|c|c|c|}
\hline Title & Conditions & Phase & Subjects & Duration & $\begin{array}{l}\text { Interventions } \\
\text { Given }\end{array}$ & Measures & $\begin{array}{c}\text { Results in Berberine or } \\
\text { Nutraceutical } \\
\text { Combination Groups }\end{array}$ \\
\hline $\begin{array}{l}\text { Nutraceutical } \\
\text { combination in patients } \\
\text { with low-grade } \\
\text { systemic inflammation } \\
\text { (berberine } 200 \mathrm{mg}, \\
\text { monacolin } \mathrm{K} 3 \mathrm{mg}, \\
\text { chitosan } 10 \mathrm{mg} \text {, and } \\
\text { coenzyme Q } 10 \mathrm{mg} \text { ) }\end{array}$ & $\begin{array}{l}\text { Atherosclerosis } \\
\text { inflammation } \\
\text { Hyperchole- } \\
\text { sterolemia }\end{array}$ & Phase 4 & $\begin{array}{l}100 \text { adults aged } 25 \text { to } 75 \text { with } \\
\text { suboptimal LDL cholesterol levels } \\
\text { (LDL } 100-160 \mathrm{mg} / \mathrm{dL} \text { ) and hsCRP } \\
\text { levels of }>2 \mathrm{mg} / \mathrm{L} \text {, randomized after } \\
30 \text { days of a low-cholesterol diet }\end{array}$ & 3 months & $\begin{array}{c}\text { Nutraceutical } \\
\text { combination: red } \\
\text { yeast rice extract } \\
\text { (monacolins), } \\
\text { policosanol, } \\
\text { berberine, folic acid, } \\
\text { coenzyme Q10, and } \\
\text { astaxanthin with a } \\
\text { low- } \\
\text { cholesterol/low- } \\
\text { saturated fat diet } \\
\text { and a regular } \\
\text { aerobic physical } \\
\text { activity schedule } \\
\text { versus a low- } \\
\text { cholesterol/low- } \\
\text { saturated fat diet } \\
\text { and a regular } \\
\text { aerobic physical } \\
\text { activity schedule + } \\
\text { placebo }\end{array}$ & $\begin{array}{l}\text { - Change in LDL cholesterol } \\
\text { Change from baseline in } \\
\text { circulation endothelial } \\
\text { microparticles } \\
\text { - Change in CRP }\end{array}$ & 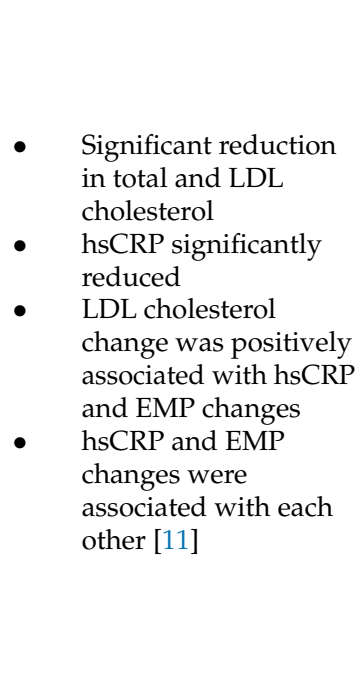 \\
\hline
\end{tabular}


Table 1. Cont.

\begin{tabular}{|c|c|c|c|c|c|c|c|}
\hline Title & Conditions & Phase & Subjects & Duration & $\begin{array}{l}\text { Interventions } \\
\text { Given }\end{array}$ & Measures & $\begin{array}{l}\text { Results in Berberine or } \\
\text { Nutraceutical } \\
\text { Combination Groups }\end{array}$ \\
\hline $\begin{array}{l}\text { The efficacy and } \\
\text { tolerability of } \\
\text { coleosoma nutraceutical } \\
\text { formulations in } \\
\text { dyslipidemic subjects } \\
\text { (fermented red rice, } \\
\text { berberine, and chitosan) }\end{array}$ & Dyslipidemias & Phase 2 & $\begin{array}{l}39 \text { adults aged } 18 \text { to } 75 \text { with } \\
\text { non-HDL cholesterol } \geq 160 \mathrm{mg} / \mathrm{dL}\end{array}$ & 12 weeks & $\begin{array}{l}\text { Coleosoma- } \\
\text { patented dietary } \\
\text { supplement } \\
\text { composed of } \\
\text { berberin, fermented } \\
\text { red rice from } \\
\text { monascus } \\
\text { purpureus } \\
\text { (monacolin K), } \\
\text { chitosan, and } \\
\text { coenzyme Q10 }\end{array}$ & 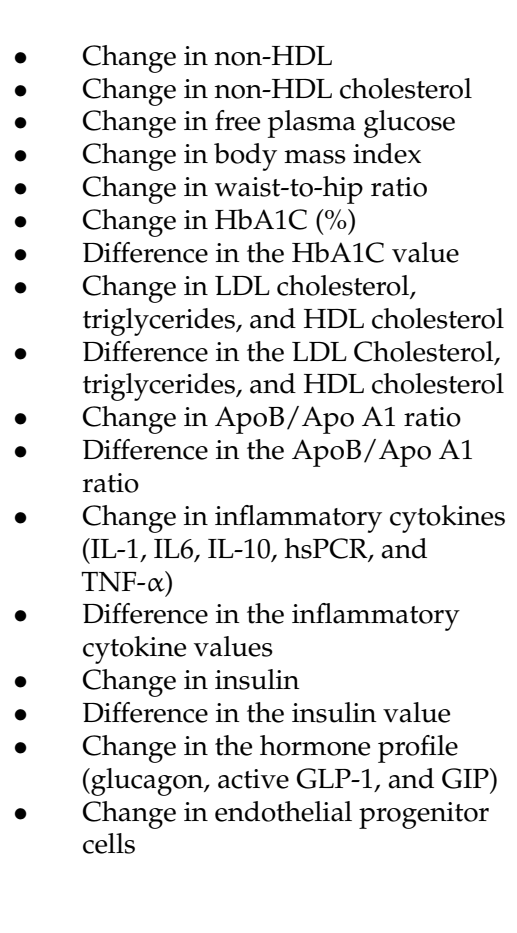 & $\begin{array}{ll}\text { - } & \text { Significantly reduced } \\
\text { non-HDL-C } \\
\text { Non-HDL-C } \\
\text { significantly } \\
\text { decreased } \\
\text { Significant correlation } \\
\text { between baseline level } \\
\text { of non-HDL-C and the } \\
\text { reduction observed } \\
\text { after } 12 \text { weeks of } \\
\text { treatment } \\
\text { Significant reduction } \\
\text { in LDL-C and } \\
\text { apolipoprotein (Apo) } \\
\text { B } \\
\text { No changes were } \\
\text { observed between } \\
\text { treatment arms in } \\
\text { HDL-C, triglycerides, } \\
\text { fasting plasma glucose } \\
\text { (FPG), glycated } \\
\text { hemoglobin (HbA1C), } \\
\text { waist circumference, } \\
\text { and body mass index } \\
\text { Differences in } \\
\text { ApoB/ApoA ratio did } \\
\text { not reach statistical } \\
\text { significance [12] }\end{array}$ \\
\hline
\end{tabular}


Table 1. Cont.

\begin{tabular}{|c|c|c|c|c|c|c|c|}
\hline Title & Conditions & Phase & Subjects & Duration & $\begin{array}{l}\text { Interventions } \\
\text { Given }\end{array}$ & Measures & $\begin{array}{c}\text { Results in Berberine or } \\
\text { Nutraceutical } \\
\text { Combination Groups }\end{array}$ \\
\hline $\begin{array}{l}\text { Combined effects of } \\
\text { bioactive compounds } \\
\text { on the lipid profile } \\
\text { (red yeast rice and } \\
\text { policosanol composed } \\
\text { of berberine, folic acid, } \\
\text { and coenzyme Q10 } \\
\text { (Armolipid Plus }{ }^{\circledR}, \\
\text { Rottapharm)) }\end{array}$ & $\begin{array}{l}\text { Hyperlipidemia } \\
\text { Low-density- } \\
\text { lipoprotein- } \\
\text { type } \\
\text { Elevated } \\
\text { triglycerides }\end{array}$ & $\begin{array}{l}\text { Phase } 2 \\
\text { Phase } 3\end{array}$ & $\begin{array}{l}118 \text { adults with } \\
\text { LDL-C plasma levels } \geq 130 \mathrm{mg} / \mathrm{dL} \\
\text { and } \leq 189 \mathrm{mg} / \mathrm{dL} \text { that did not } \\
\text { require lipid-lowering drug } \\
\text { treatment according to the ATPIII } \\
\text { guidelines, as well as adults that did } \\
\text { not have cardiovascular disease, } \\
\text { stroke, intermittent claudication, } \\
\text { diabetes mellitus, renal issues, or } \\
\text { effects/contraindications to } \\
\text { lipid-lowering drug therapy }\end{array}$ & 12 weeks & $\begin{array}{l}\text { Armolipid Plus (red } \\
\text { yeast, astaxanthin, } \\
\text { berberine, } \\
\text { policosanol, } \\
\text { coenzyme Q10, and } \\
\text { folic acid) versus } \\
\text { placebo }\end{array}$ & $\begin{array}{ll}- & \text { LDL-C levels } \\
- & \text { Cardiovascular risk } \\
- & \text { Criteria for Metabolic Syndrome } \\
\text { cevels of triglycerides and } \\
\text { cholesterol high-density } \\
\text { lipoprotein (HDL-C) }\end{array}$ & $\begin{array}{ll}\text { - } & \text { Plasma LDL-C } \\
\text { reduced } \\
\text { - } & \text { AC was reduced } \\
\text { - } & \text { reduced } \\
\text { The ratios of } \\
\text { TC/HDL-C were } \\
\text { reduced } \\
\text { The ratios of } \\
\text { LDL-C/HDL-C were } \\
\text { reduced } \\
\text { The ratios of } \\
\text { ApoB-100/ApoA-1 } \\
\text { were reduced } \\
\text { No statistically } \\
\text { significant changes } \\
\text { were observed in TG } \\
\text { and HDL-C levels } \\
\text { The body mass index } \\
\text { was reduced } \\
\text { The weight loss } \\
\text { observed in the AP } \\
\text { consumption group } \\
\text { had no significant } \\
\text { impact on LDL-C } \\
\text { reduction, Apo B-100, } \\
\text { TC/HDL-C ratio, or } \\
\text { on the ApoB/ApoA1 } \\
\text { ratio } \\
\text { Non-significant } \\
\text { contribution of } \\
\text { weight-loss to LDL-C } \\
\text { reduction [13] }\end{array}$ \\
\hline
\end{tabular}


Table 1. Cont.

\begin{tabular}{|c|c|c|c|c|c|c|c|}
\hline Title & Conditions & Phase & Subjects & Duration & $\begin{array}{l}\text { Interventions } \\
\text { Given }\end{array}$ & Measures & $\begin{array}{c}\text { Results in Berberine or } \\
\text { Nutraceutical } \\
\text { Combination Groups }\end{array}$ \\
\hline $\begin{array}{l}\text { Effects of nutraceutical } \\
\text { therapies on endothelial } \\
\text { function, platelet } \\
\text { accumulation, and } \\
\text { coronary flow reserve }\end{array}$ & $\begin{array}{l}\text { Hypercholesterolem } \\
\text { Endothelial } \\
\text { dysfunction }\end{array}$ & $\begin{array}{l}\text { nia Not } \\
\text { Applicable }\end{array}$ & $\begin{array}{c}\text { Adults aged between } 18 \text { and } \\
70 \text { years with hypercholesterolemia } \\
\text { that did not require statins or were } \\
\text { statin-intolerant }\end{array}$ & 8 weeks & $\begin{array}{l}\text { Combination A } \\
\text { (Armolipid Plus): } \\
\text { policosanol, red } \\
\text { yeast rice } \\
\text { (monacolin K), } \\
\text { berberine, } \\
\text { astaxantine, folic } \\
\text { acid and coenzyme } \\
\text { Q10 or combination } \\
\text { B: berberine, red } \\
\text { yeast rice powder } \\
\text { (monacolin K), and } \\
\text { leaf extract of } \\
\text { Morus alba }\end{array}$ & 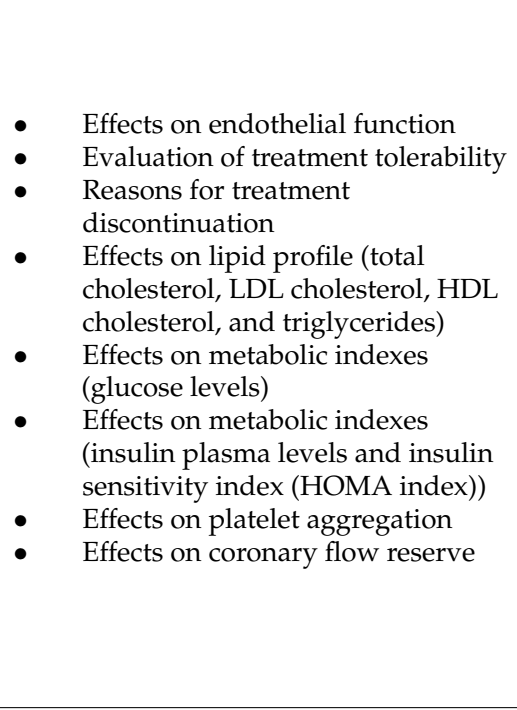 & $\begin{array}{l}\text { Reduced LDL } \\
\text { cholesterol below } \\
130 \mathrm{mg} / \mathrm{dL} \text { in } 56.5 \% \text { of } \\
\text { patients } \\
\text { (Combination A) } \\
\text { Reduced plasma } \\
\text { levels of triglycerides, } \\
\text { total and LDL } \\
\text { cholesterol, and } \\
\text { increased HDL } \\
\text { cholesterol } \\
\text { Total and LDL } \\
\text { cholesterol reduction } \\
\text { (Combination B). } \\
\text { Reduced plasma } \\
\text { levels of glycated } \\
\text { hemoglobin, fasting } \\
\text { glucose, and insulin, } \\
\text { as well as the HOMA } \\
\text { index (Combination } \\
\text { B) [14] }\end{array}$ \\
\hline $\begin{array}{l}\text { Study of berberine } \\
\text { hydrochloride in the } \\
\text { prevention of colorectal } \\
\text { adenomas recurrence }\end{array}$ & $\begin{array}{c}\text { Colorectal } \\
\text { adenoma }\end{array}$ & Phase 2 & $\begin{array}{l}1108 \text { adults sged } 18-75 \text { who had at } \\
\text { least one, and no more than } 6, \\
\text { histologically confirmed colorectal } \\
\text { adenomas that were removed within } \\
6 \text { months before recruitment, whose } \\
\text { adenoma was not completely } \\
\text { removed during a previous } \\
\text { colonoscopy; a history of familial } \\
\text { adenomatous polyposis or } \\
\text { hereditary non-polyposis colorectal } \\
\text { cancer (HNPCC, Lynch syndrome); } \\
\text { or a history of subtotal/total } \\
\text { gastrectomy or partial bowel } \\
\text { resection }\end{array}$ & 3 years & $\begin{array}{c}\text { Berberine } \\
\text { hydrochloride } \\
\text { versus placebo }\end{array}$ & 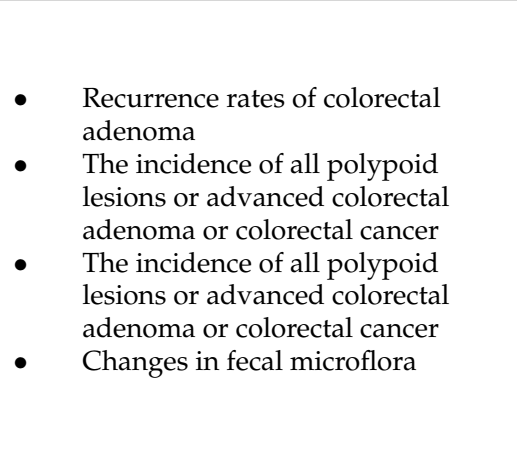 & $\begin{array}{l}\text { Berberine } 0,3 \mathrm{~g} \text { twice } \\
\text { daily was effective } \\
\text { and safe } \\
\text { The risk of the } \\
\text { recurrence of } \\
\text { colorectal adenoma } \\
\text { was reduced [15] }\end{array}$ \\
\hline
\end{tabular}


Table 1. Cont.

\begin{tabular}{|c|c|c|c|c|c|c|c|}
\hline Title & Conditions & Phase & Subjects & Duration & $\begin{array}{l}\text { Interventions } \\
\text { Given }\end{array}$ & Measures & $\begin{array}{c}\text { Results in Berberine or } \\
\text { Nutraceutical } \\
\text { Combination Groups }\end{array}$ \\
\hline $\begin{array}{l}\text { Berberine effects on } \\
\text { clinical symptoms and } \\
\text { metabolic disturbance } \\
\text { in patients with } \\
\text { schizophrenia }\end{array}$ & Schizophrenia & Phase 4 & $\begin{array}{c}65 \text { adults aged } 18 \text { to } 65 \text { years who } \\
\text { met the diagnosis of schizophrenia } \\
\text { according to the DSM-IV, and have } \\
\text { undergone monotherapy of atypical } \\
\text { antipsychotics for } 4 \text { weeks or more, } \\
\text { with at least } 60 \text { for positive and } \\
\text { negative syndrome scale }\end{array}$ & 8 weeks & $\begin{array}{l}\text { Berberine plus any } \\
\text { atypical } \\
\text { antipsychotic drug } \\
\text { as the basic } \\
\text { treatment }\end{array}$ & $\begin{array}{ll}\text { - } & \text { Positive and Negative Syndrome } \\
& \text { Scale } \\
\text { - } & \text { Changes in Insulin } \\
\text { - } & \text { Changes in TC } \\
\text { - } & \text { Changes in TG } \\
\text { - } & \text { Chafety of berberine } \\
\text { - } & \text { Changes in CRP } \\
\text { - } & \text { Changes in IL-1 } \beta \\
& \text { Changes in IL-6 TNF- } \alpha\end{array}$ & 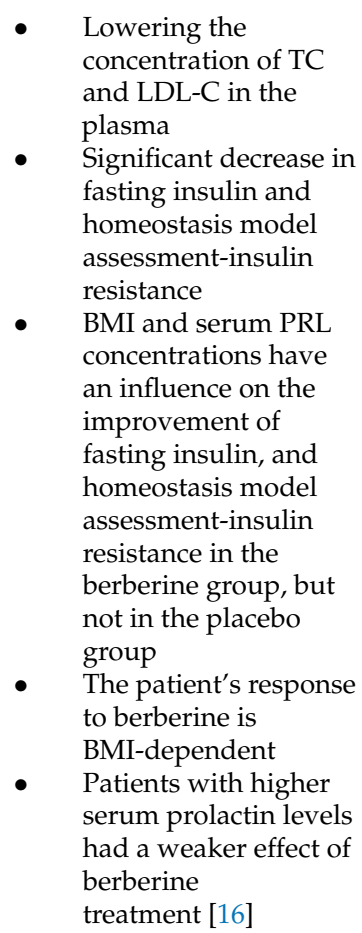 \\
\hline
\end{tabular}


Table 1. Cont.

\begin{tabular}{|c|c|c|c|c|c|c|c|}
\hline Title & Conditions & Phase & Subjects & Duration & $\begin{array}{l}\text { Interventions } \\
\text { Given }\end{array}$ & Measures & $\begin{array}{c}\text { Results in Berberine or } \\
\text { Nutraceutical } \\
\text { Combination Groups }\end{array}$ \\
\hline $\begin{array}{l}\text { Berberine treat } \\
\text { metabolic syndrome in } \\
\text { schizophrenia }\end{array}$ & $\begin{array}{c}\text { Metabolic } \\
\text { syndrome } \\
\text { Schizophrenia }\end{array}$ & $\begin{array}{c}\text { Not } \\
\text { Applicable }\end{array}$ & $\begin{array}{l}\text { Adult females aged } 18-60 \text { with a } \\
\text { diagnosis of schizophrenia, } \\
\text { undergoing monotherapy of atypical } \\
\text { antipsychotics for } 2 \text { weeks or more, } \\
\text { including olanzapine, clozapine, } \\
\text { risperidone, and perphenazine, with } \\
\text { a diagnosed metabolic syndrome } \\
\text { depending on the guidelines for the } \\
\text { prevention and treatment of } \\
\text { dyslipidemia in Chinese adults } \\
\text { in } 2007\end{array}$ & 8 weeks & $\begin{array}{c}\text { Berberine in } \\
\text { adjunctive group }\end{array}$ & $\begin{array}{ll}\text { - } & \text { Serum fasting blood glucose } \\
\text { - } & \text { Serum triglyceride and serum } \\
\text { - } & \text { low-density lipoprotein } \\
\text { - } & \text { Waistline circumference } \\
\text { - } & \text { Diastolic blood pressure }\end{array}$ & $\begin{array}{l}\text { - Control of weight gain } \\
\text { and other metabolic } \\
\text { symptoms associated } \\
\text { with antipsychotic } \\
\text { therapy as an adjuvant } \\
\text { Significant differences } \\
\text { in body weight, BMI, } \\
\text { and leptin } \\
\text { Significant positive } \\
\text { correlations with } \\
\text { changes in body } \\
\text { weight } \\
\text { There was no } \\
\text { significant difference } \\
\text { in adverse events } \\
\text { between the two } \\
\text { groups [17] }\end{array}$ \\
\hline $\begin{array}{c}\text { Berberine } \\
\text { hyperglycemic clamp }\end{array}$ & $\begin{array}{l}\text { Diabetes } \\
\text { mellitus }\end{array}$ & Phase 1 & $\begin{array}{l}15 \text { adult healthy males, aged } 18-45 \\
\text { with BMI } 18-25 \mathrm{~kg} / \mathrm{m}^{2} \text { and a normal } \\
\text { oral glucose tolerance test prior to } \\
\text { the study, with no family history of } \\
\text { diabetes mellitus, and with no } \\
\text { medication treatment within } 4 \\
\text { weeks prior to the baseline visit, as } \\
\text { well as during the study }\end{array}$ & 2 weeks & $\begin{array}{l}\text { Berberine versus } \\
\text { placebo }\end{array}$ & $\begin{array}{ll}\text { - } & \text { Differences in serum insulin levels } \\
& \text { Differences in serum C-peptide } \\
\text { - } & \text { Diffels } \\
& \text { rates } \\
\text { - } & \text { Differences in glucose infusion } \\
\text { - Heart rate and QT-interval } \\
\text { duration }\end{array}$ & 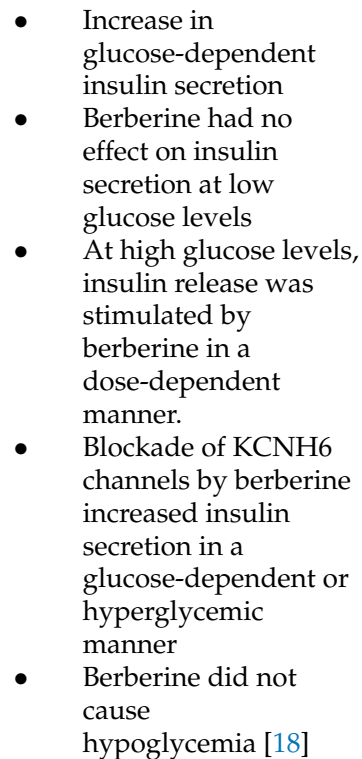 \\
\hline
\end{tabular}


Table 1. Cont.

\begin{tabular}{|c|c|c|c|c|c|c|c|}
\hline Title & Conditions & Phase & Subjects & Duration & $\begin{array}{c}\text { Interventions } \\
\text { Given }\end{array}$ & Measures & $\begin{array}{c}\text { Results in Berberine or } \\
\text { Nutraceutical } \\
\text { Combination Groups }\end{array}$ \\
\hline $\begin{array}{l}\text { Efficacy and safety of } \\
\text { berberine in the } \\
\text { treatment of diabetes } \\
\text { with dyslipidemia }\end{array}$ & $\begin{array}{c}\text { Type } 2 \text { diabetes } \\
\text { mellitus } \\
\text { Metabolic } \\
\text { syndrome }\end{array}$ & Phase 3 & $\begin{array}{c}120 \text { adults aged } 25-70 \text { with newly } \\
\text { diagnosed type } 2 \text { diabetes, according } \\
\text { to the } 1999 \text { World Health } \\
\text { Organization criteria, with } \\
\text { dyslipidemia with a TG of } \\
>150 \mathrm{mg} / \mathrm{dL}(1.70 \mathrm{mmol} / \mathrm{L}), \\
\text { and } / \mathrm{or} \mathrm{TC}>200 \mathrm{mg} / \mathrm{dL} \\
(5.16 \mathrm{mmol} / \mathrm{L}), \text { and } / \text { or } \\
\text { LDL-C }>100 \mathrm{mg} / \mathrm{dL}(2.58 \mathrm{mmol} / \mathrm{L}), \\
\text { according to the National } \\
\text { Cholesterol Education Program's } \\
\text { Adult Treatment Panel III (NCEP: } \\
\text { ATPIII) without previous treatment } \\
\text { and with BMI } 19-40 \mathrm{~kg} / \mathrm{m}^{2}\end{array}$ & 3 months & $\begin{array}{l}\text { Berberine versus } \\
\text { placebo }\end{array}$ & $\begin{array}{ll}\text { - } & \text { Fasting glucose levels } \\
\text { - } & \text { OGTT } 2 \text { h glucose levels } \\
\text { - } & \text { HbA1c } \\
\text { - } & \text { Serum triglycerides } \\
\text { - } & \text { HDL-C } \\
\text { - } & \text { LDL-C } \\
\text { - } & \text { Glucose dispososal rate } \\
\text { - } & \text { Blood pressure }\end{array}$ & $\begin{array}{l}\text { - After } 3 \text { months of } \\
\text { treatment, plasma } \\
\text { glucose levels in the } \\
\text { front and under loads } \\
\text { were significantly } \\
\text { reduced [17] }\end{array}$ \\
\hline $\begin{array}{l}\text { Therapeutic effects of } \\
\text { berberine in patients } \\
\text { with type } 2 \text { diabetes }\end{array}$ & Type 2 diabetes & $\begin{array}{l}\text { Phase } 1 \\
\text { Phase } 2\end{array}$ & $\begin{array}{l}70 \text { adults aged } 25 \text { to } 75 \text { with a clinical } \\
\text { diagnosis of type } 2 \text { diabetes with } \\
\text { HbA1c }>7.0 \% \text { or FBG }>7.0 \mathrm{mmol} / \mathrm{L} \\
\text { with stable or worsening glycemic } \\
\text { control for at least } 3 \text { months }\end{array}$ & 13 weeks & $\begin{array}{c}\text { Berberine versus } \\
\text { metformin }\end{array}$ & $\begin{array}{ll}- & \text { HbA1c } \\
- & \text { Blood glucose } \\
\text { - } & \text { Blood lipids }\end{array}$ & 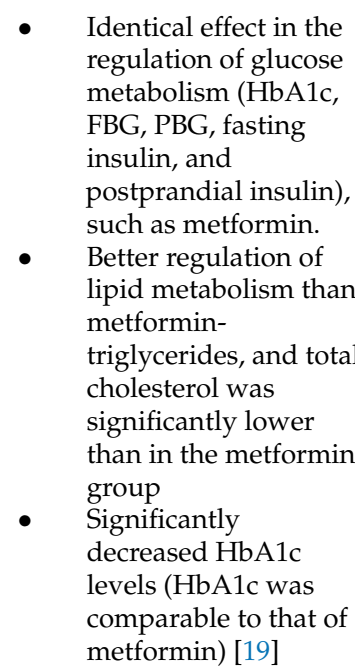 \\
\hline
\end{tabular}




\section{Antidiabetic Action of Berberine}

The metabolic syndrome is, among others, defined as a cluster of glucose intolerance, central obesity, and insulin resistance as the source of pathogenesis. Today, the fight against insulin resistance and obesity concerns a growing group of ever-younger patients. It has also become a key point in the fight against infertility. Berberine antidiabetic properties in T2DM were first documented in 1986 [20] and its antidiabetic activity has been proven in vivo [21-23]. Its antidiabetic activity is the best-studied potential therapeutic application of berberine. Unfortunately, despite its beneficial effects and high safety profile, its poor bioavailability is still a limitation in its clinical application.

Previous research showed that berberine mitigates insulin resistance [24], and the reduction in alanine and aspartate transaminase levels, in patients with T2DM [20]. Furthermore, it was shown that berberine positively contributed to elevated levels of fasting and postprandial blood glucose and glycosylated hemoglobin, while decreasing insulin resistance.

Berberine stimulates glycolysis by increasing the activity of glucokinases, improving insulin secretion, and inhibiting gluconeogenesis and adipogenesis in the liver [25-27]. By the activation of 5-adenosine monophosphate kinase (AMPK), it improves insulin sensitivity in individuals with insulin resistance and increases the translocation of the glucose- 4 transporter into the plasma. It has also been reported that, in individuals with insulin resistance, where the signaling pathway of protein kinase B (Akt) is impaired, berberine increases Akt phosphorylation and, thus, activates Akt, precisely by the activation of AMPK. According to scientific reports, the pathways through which berberine regulates glucose uptake may be diverse, but the activation of the AMPK pathway is the most likely. Berberine also enhances the expression of the AMPK-dependent adipose tissue triglyceride lipase, which is positively associated with long-term weight loss and is one of the mechanisms of action in the prevention of obesity [20].

Berberine has also been shown to increase glucose-stimulated insulin secretion [25]. As has been shown both in vitro and in vivo, the compound increases insulin secretion in islet cells by increasing the level of glucagon-like peptide-1 (GLP-1) [28]. As berberine inhibits glycosidase, it may also reduce glucose transport across the intestinal epithelium. Thus, it may exert an antihyperglycemic effect [29]. However, it is poorly absorbed after oral administration, and only nanomolar plasma concentrations can be achieved both in humans and animals [30]. Due to its high therapeutic potential, it is compared to metformin. Simultaneously, the high efficacy and safety profile gives berberine some advantages in its use, e.g., in patients who do not tolerate metformin therapy. Not only does berberine appear to produce significantly better results than metformin in blood glucose regulation, it also supersedes the benefits of rosiglitazone by improving fasting blood glucose levels. Although further research on the efficacy of berberine administered to patients with T2DM is needed [31], the prospects of combining oral hypoglycemic medications with berberine result in positive outcomes. Similar to metformin, berberine controls several effectors, such as mitogen-activated protein kinase [32].

The mechanism of berberine efficacy in obesity is also being currently intensively investigated, especially in cases connected with T2DM. The influence of berberine on insulin resistance was clinically evaluated in obese women with polycystic ovary syndrome, and improved insulin resistance was indicated [33,34]. In obese patients with cardiometabolic syndrome risk factors [35], the improvement of lipid parameters (total cholesterol, LDL, TG, the cholesterol/HDL ratio, and the TG/HDL ratio), weight, and fat mass loss were observed. In obese patients, c-Jun N-terminal kinases (JNK) [36] and excitotoxic neurotransmitters are involved in the development of insulin resistance in ischemic conditions [37], and berberine affects the lipid metabolic pathways mediated by those kinases, as well as acting as a neuroprotectant. This activity also translates into its anticancer properties, as discussed below [38-41]. Additionally, the influence on body mass has been found in several mechanisms that were confirmed in humans, and it is partially connected with its antidiabetic actions. In vitro studies have shown that berberine significantly decreased the amount and size of lipid droplets found in the 3t3-L1 adipocyte cell lines. Berberine has been 
clinically shown to inhibit $\alpha$-glycosidase [32]. There was also a clinically proven inhibitory effect on adipocyte differentiation by reducing the expression of liver $X$ receptor alpha, the peroxisome proliferator-activated receptor (PPAR $\gamma$ ), and the sterol element-binding protein1 receptor (SREBP). Berberine also enhances basal triglyceride lipolysis in adipocytes, and inhibits the separation and augmentation of preadipocytes and adipocytes through the PPAR $\gamma$ and CCAAT/enhancer-binding protein $\alpha$ pathways [20]. These mechanisms underlie the understanding of the effects of berberine on the treatment and prevention of obesity.

Regarding polycystic ovary syndrome, berberine's efficacy is currently being investigated and the outcomes are important for the treatment of patients with this condition. Research suggests the high potential of berberine administration in patients with polycystic ovarian syndrome, as it reduces insulin resistance and improves ovulation [42]. Three months of $500 \mathrm{mg}$ of berberine treatment showed a significant improvement in the lipid profile 3 in 26 patients with polycystic ovary syndrome, as well as increasing the pregnancy rate and decreasing the appearance of severe ovarian hyperstimulation syndrome [43]. Substituting metformin with berberine also resulted in a decrease in the negative effects, lower lipid parameters, and body mass index (BMI) in such patients [24]. Further research showed that berberine, combined with Yasmin, has been described to significantly improve sex hormones and glucose metabolism [20].

In addition, berberine, combined with letrozole, has a synergistic effect on ovulation induction in polycystic ovary syndrome with insulin resistance. The effect is better than metformin combined with letrozole. Berberine can significantly improve ovulation rates [44]. On the other hand, another study [45] revealed that letrozole, combined with berberine, did not improve fertility in patients with polycystic ovary syndrome, to some extent [46].

Currently, researchers pay high attention to the role of nutraceuticals in T2DM, and some of them are being intensively investigated. Some nutraceuticals have been reported to decrease postprandial and fasting glucose levels in plasma, glycated hemoglobin, and fasting plasma insulin. Several clinical trials and further research indicated that berberine, as a nutraceutical, amalgamated with chromium picolinate, inositol, curcumin, and banaba, was positively associated with the reduction in inflammation in patients with dysglycemia, as well as the improvement in glycometabolic compensation, triglycerides, and cholesterol values. Research has shown that the level of the high-sensitivity C-reactive protein (CRP) in patients with fasting dysglycemia decreased after 3 months of combined nutraceutical treatment [47]. The combination of berberine and Bifidobacteria administered to patients with pre-diabetes and diabetes mellitus also indicated their supportive roles in diabetes treatment [15].

\section{The Cholesterol-Lowering Effect of Berberine}

An abnormal lipid profile characterizes patients with the metabolic syndrome. It is a disease component, or risk factor, for the appearance of the metabolic syndrome, and is characterized by elevated serum triglycerides, LDL, and low HDL cholesterol levels. Although the causes of lipid metabolism disorders can be complex, nutrition modification is one of the key avenues for the prevention and treatment of cholesterol-related disorders that are associated with metabolic syndrome. Apart from basic nutritional changes, the use of nutraceuticals, or the supplementation of plant compounds with proven biological activity, such as extracts or individual plant compounds, appear to be useful today.

Berberine is one of the plant metabolites with a high interest nowadays, with a beneficial effect on the lipid profile, and the mechanism of its action in this area has already been partially ascertained. The primary mechanism for lowering cholesterol is the inhibition of intestinal absorption by interfering with the cholesterol micellization in the gut, and by reducing cholesterol absorption and secretion by enterocytes [48]. The compound also stimulates the accumulation of bile acids [49], regulates the excretion of cholesterol, and stimulates the removal of LDL cholesterol from the blood [50,51]. Molecularly, as described 
above, berberine stimulates the AMPK responsible for fatty acid synthesis [32]. Berberine has also been shown to regulate liver cholesterol biosynthesis through the increased phosphorylation of 3-hydroxy-3-methylglutaryl coenzyme A reductase, which catalyzes the rate-limiting step in cholesterol biosynthesis [52].

Clinical trials have confirmed the antisclerotic activity of berberine. Elevated levels of HDL, TG, and LDL, and decreased levels of TG, have been demonstrated in patients after 3 months of berberine treatment [53]. Significant reductions in blood glucose and insulin, after standard mixed meals, and increased flow-mediated dilation and a significant reduction in arterial systolic blood pressure were observed [10]. Recent clinical reports state that, in addition to the beneficial effect on the lipid profile, berberine increases the level of testosterone in men, which may reduce the risk of developing cardiovascular diseases. Importantly, previous studies have shown that berberine (1500 mg/day for 3 months) reduced testosterone in women with PCOS [8].

As described earlier, the nutraceutical combinations seem to also play a role in the modulation of the lipid profile, and they have been clinically assessed. Several berberinecontaining nutraceutical mixtures have been evaluated in clinical trials and have shown promising effects in patients with an abnormal lipid profile. One of them, conducted in patients with a low-to-moderate risk of hypercholesterolemia, has revealed that the combinations of nutraceuticals containing berberine, policosanol, and red yeast rice extract reduces the total cholesterol and LDL after 4 weeks. There were no significant changes in $\mathrm{HDL}$, fasting glucose, and the serum triglycerides concentrations in any of the study groups, and the complex was safe and well-tolerated [9]. In patients with low-grade systemic inflammation, the oral administration of red yeast rice, berberine, and policosanol improved the lipid profile and attenuated the degree of systemic inflammation and endothelial injury. A significant reduction in total cholesterol, LDL cholesterol, high-sensitivity CRP, and endothelial microparticles were also observed in these patients [11]. The combination of berberine, with fermented red rice and chitosan, significantly reduced non-HDL-C, LDL-C, and apolipoprotein B after 12 weeks of treatment, compared to the placebo. On the other hand, there were no changes that were observed between the treatment arms in HDL-C, triglycerides, fasting plasma glucose, glycated hemoglobin (HbA1C), the waist circumference, and BMI [12].

Clinical studies have also shown that, after 12 weeks of the administration of berberine, in combination with chlorogenic acid and tocotrienols, in menopausal women at risk of dyslipidemia, cholesterol and LDL levels were reduced. Further studies on the influence of berberine on the symptoms of menopause are necessary. Furthermore, the side effects of berberine are minimal, and mainly affect the digestive system [54].

Berberine was also assessed in combination with changes in lifestyle. Studies showed that in patients with non-alcoholic fatty liver disease, berberine, combined with lifestyle changes, contributed to a significant loss of liver fat, body weight, and an improved serum lipid profile, much more so than in patients who adapted only to a new lifestyle or the use berberine as supplements alone. In this study, berberine also weakened the efficacy of pioglitazone and indicated its regulatory capacity for lipid metabolism in the liver [55].

The effect of berberine, as well as its activity in combination with nutraceuticals, is undoubtedly beneficial in patients with a disturbed lipid profile. Consequently, it is interesting from the point of view of preventing the occurrence of cardiovascular diseases, because hypercholesterolemia is considered one of the most important cardiovascular risk factors.

\section{Berberine and Gut Microbiota}

Berberine may also reduce the risk of developing the metabolic syndrome through its beneficial effects on the gut microbiota. In the last decade, many studies have indicated that the composition of gut microbiota is associated with the regulation of the host's health and metabolism. Dysbiosis, defined as an alteration in the quality and/or quantity of the intestinal microbiota, can affect the host's physiology [56] and may be a factor that 
leads to the onset of various diseases, including obesity and T2DM [57-59], as well as cardiovascular diseases, Crohn's disease, and cancer [60,61]. Obesity and T2DM are closely related to a low-grade inflammatory state with the abnormal expression and production of many inflammatory mediators, such as interleukins and tumor necrosis factors [48]. Understanding the molecular mechanism of the action of berberine is still poor, and due to its very low bioavailability after oral administration, it seems highly likely that it acts by affecting the composition of the gut microbiota. The impact on the host's metabolic homoeostasis has been implicated in several microbial metabolic pathways that regulate the production or transport of amino acids, short-chain fatty acids (SCFA), or bile acids (BA) [62-64]. Recent studies have shown that obesity is related to a higher number of Firmicute phylum and a relatively lower number of the phylum Bacteroidetes $[65,66]$, whereas another study indicated that the proportion of Firmicute phylum and the Clostridia class in the intestinal tracts of patients was relevantly reduced [67]. The disturbance in the Firmicutes / Bacteroidetes ratio, which are two major components of the gut microbiota, was observed in many pathological conditions. In obesity, the Firmicutes/Bacteroidetes ratio is shifted into a higher content of Firmicutes, and berberine administration at a dose of $150 \mathrm{mg} / \mathrm{kg}$ is able to restore the balance, by declining Firmicutes abundance and slightly increase in Bacteroidetes [68]. Another study has shown that berberine, administrated at a dose of $200 \mathrm{mg} / \mathrm{kg}$ for six weeks, relevantly diminished the relative abundances of phylum Bacteroidetes and Firmicutes in the gut of high-fat diet-fed mice, and its antimicrobial activities may result in a lower degradation of dietary polysaccharides, decreasing the potential calorie intake, and, subsequently, systemically increasing fasting-induced adipose factor gene expression in visceral adipose tissues [69].

The disturbance in the ratio of Firmicutes / Bacteroidetes in the gut microbiota could be associated with a variety of diseases, including obesity [70]. It has also been proven that berberine reduces the diversity of the gut microbiome and changes the relative abundance of Eubacterium, Desulfovibrio, and Bacteroides [71]. In the course of inflammatory diseases of the digestive system, such as inflammatory bowel disease or colitis, berberine can decrease the prevalence of harmful bacteria, such as Enterococci and E. coli, and can increase the total relative abundance of Lactobacilli and Bifidobacteria [72]. Lactobacillus sp., a member of Firmicutes, was found to be inhibited by berberine in vitro [73]. An experiment on mice (C57BL/6) has shown that berberine, at a dose of $300 \mathrm{mg} / \mathrm{kg}$, reduced the populations of Ruminococcus schinkii, Ruminococcus gnavu, Lactococcus lactis, Lactobacillus acidophilus, and Lactobacillus murinus, and enriched the population of Bacteroides [74]. This study has also evaluated the impact of berberine on the profile of bile acids and the gut microbiota. Tian and colleagues have reported that the short-term intake of berberine at a dose of $100 \mathrm{mg} / \mathrm{kg}$ alters gut microbiota by lowering Clostridium clusters IV and XIVa, as well as their bile salt hydrolase activity, which leads to the accumulation of taurocholic acid. Taurocholic acid may activate the intestinal farnesoid X receptor (FXR), which can influence lipid, glucose, and bile acid metabolism [75]. Many observational studies have indicated a connection between elevated levels of circulating branched-chain amino acids (BCAAs) and a poor metabolic condition. High BCAA blood levels are positively correlated with insulin resistance. Berberine has ability to reduce the relative abundance of BCAA-producing bacteria, including Clostridiales; the families of Streptococcaceae, Clostridiaceae, the Streptococcus genera; and Prevotella [76]. Berberine can also regulate the circulating levels of BCAAs and improve glycemic control in both healthy participants and patients with T2DM [77]. Berberine fumarate, an organic acid derivative of berberine, has a better oral bioavailability, reducing inflammation, inhibiting the overexpression of the toll-like receptors and phosphorylated c-Jun N-terminal kinases, increasing the expression of glucose transporter-2, phosphoinositide 3-kinase, and other proteins related to oxidative stress that lead to alleviated metabolic disorders and an improved control of glucose metabolism in T2DM [71].

It has been also reported that berberine affects the bacteria that produce short-chain fatty acids and bile acids in the gut microbiome $[78,79]$. Bile acids regulate blood levels of cholesterol, triglycerides, glucose, and energy homeostasis. This may prove that berberine 
acts in a similar manner to some anti-diabetic drugs, such as acarbose and metformin, by modifying the gut microbiota and, thereby, altering the composition of bile acid and increasing the ratio between primary and secondary bile acids, which evince proinflammatory and cytotoxic effects $[71,80,81]$. A recent study revealed that berberine, at a dose of $4 \mathrm{~g}$ per day, administered orally for 12 weeks, lowered the gut species that mainly produce SCFA or single sugars from digested polysaccharides or oligosaccharides, including Ruminococcus bromii, Faecalibacterium prausnitzii, Bifidobacterium spp., and Roseburia spp., as well as inversing two Bacteroides spp. and multiple taxa of $\gamma$-Proteobacteria. [82]. These results showed that berberine reduced the transformation of microbial bile acids, especially the production of deoxycholic acid by Ruminococcus bromii and, therefore, decreased FXR activity, which may explain its antidiabetic effect. In the liver, bile acids activate FXR, which serves as a suppressor of BA synthesis and promotes the enterohepatic circulation of bile acids. FXR induces the expression of a small heterodimer partner that suppresses the liver receptor homolog-1, leading to the lowered transcription of bile acid-synthetic enzymes-Cyp7a1 [83]. Guo and colleagues have reported that, in the livers of mice administered orally high doses of berberine $(300 \mathrm{mg} / \mathrm{kg}$ ), the expression of Cyp7a1 and Cyp8b1, and an uptake transporter, sodium taurocholate, in its co-transportation of polypeptides, were significantly increased [74]. Research has shown that some of the effects of berberine could be related to the increase in the population of SCFA-producing bacteria, which has a relevant influence on blood glucose and lipid levels $[79,84]$. SCFA, such as butyric acid, acetic acid, propionic acid, isobutyric acid, isovaleric acid, and valeric acid can mitigate the inflammation of the bowel mucosa and can enter the bloodstream, reducing lipid and glucose levels [85]. It has been shown that the treatment of high-fat diet-induced obese animals with berberine $(100 \mathrm{mg} / \mathrm{kg}$ and $200 \mathrm{mg} / \mathrm{kg}$ ) and metformin induced an increase in the total relative abundance in seven operational taxonomic units (OTUs) from less than $2 \%$ to $10-20 \%$. Six of these OTUs were major SCFA-producing bacteria, such as Bacteriodes, Blautia, Butyricoccus, and Phascolarctobacterium [86]. Zhang et al. using the mouse model of obesity, diabetes, and dyslipidemia, showed that berberine, at a dose of $136.5 \mathrm{mg} / \mathrm{kg}$, reduced body weight, food intake, blood glucose, and $\mathrm{HbA1c}$ levels, among other associated increases in the numbers of SCFA-producing bacteria (Butyricimonas, Ruminococcus, and Coprococcus), as well as reducing the population of opportunistic pathogens (Prevotella and Proteus) [87]. The upregulation of GLP-1 and peptide YY, induced by butyrate, can be relevant for the prevention and treatment of insulin resistance and obesity [88].

Most of obtained data derived from animal models, and further studies on human are required to assess these findings because they do not relate mutually. We still do not have detailed knowledge on how the host's gut microbiota responds to berberine intake and to what extent changes in gut flora composition are related to the metabolic benefits of berberine, including its anti-obesity and anti-diabetic effects. Qin and colleagues carried out a two-stage metagenome-wide association study using deep shotgun sequencing of fecal samples to find changes in gut microbiota in a group of 345 patients with T2DM. They identified T2DM-related gut flora dysregulation, which was associated with an increase in the opportunistic species of pathogenic bacteria and a decrease in butyrate-producing bacteria, confirming previous findings in animal models [89].

\section{Anti-Inflammatory Activity of Berberine}

One of the conditions that make up the metabolic syndrome is the occurrence of chronic inflammations. They are a serious health problem for patients affected by syndrome $X$. There is a consensus that inflammatory pathways contribute to the pathogenesis of the metabolic syndrome, and new research indicates that inflammation plays a key role in the development and progression of the metabolic syndrome. However, up to today, the specific pathways associated with this disease are scantily understood. Monocytederived chemokines and cytokines promote inflammation and insulin resistance. Inflammatory biomarkers (CRP, fibrinogen, and serum amyloid A), cytokines, and chemokines have been associated with the pathogenesis of the metabolic syndrome. The treatment of 
existing inflammations using glucocorticosteroids also promotes the progression of the metabolic syndrome.

On the other hand, inflammations can also occur as a result of disorders observed over the course of the disease. In the case of obesity, adipose tissue increases the occurrence of inflammations by releasing pro-inflammatory adipokines (leptin and chemerine) and disrupting the anti-inflammatory activity of adiponectin. Most cells in the subcutaneous adipose tissue promote both inflammation and fibrosis. Inflammations may also appear as a distinct disease entity within the metabolic syndrome, such as osteoarthritis, back pain syndromes, and acute or chronic pancreatitis [90-95].

The anti-inflammatory effect of berberine has been known for several years, but it has not yet been fully understood. The compound exhibits an anti-inflammatory property both in vitro and in vivo. It curbs interleukin (IL)-1, IL-6, and tumor necrosis factor (TNF)gene transcription by diminishing levels of inflammatory proteins. It further stalls the expression of cyclooxygenase 2 (COX-2) and prostaglandin E2 [96], it halts the NF- $\mathrm{kb}$ signaling pathway, it inhibits IL-8 production in cancer cells [97], and it hinders the increase in NO and TNF- $\alpha[96,98]$. Berberine has been found to decrease the COX-2 transcriptional activity observed in colorectal cancer cells [99]. In the near future, we can expect the results of clinical trials of the effects of berberine on the levels of CRP, IL- $1 \beta$, IL- 6 , and TNF$\alpha$ [23]. The anti-inflammatory activity of berberine makes it noteworthy as a supplement or nutraceutical due to its potential to prevent the development of colorectal cancer [99].

\section{Anticancer Activity of Berberine}

An implication of the metabolic syndrome is the increased risk of some malignancies. The most common are colon cancer, esophageal adenocarcinoma, postmenopausal breast cancer, endometrial cancer, kidney cancer, non-small cell lung cancer in smokers, and liver cancer in patients with cirrhosis.

The anticancer properties of berberine are currently being studied in a very intensive way, and the results make it even more noteworthy as a potential nutraceutical for patients suffering from syndrome $X$ that are at risk of developing cancer. Due to the pharmacodynamic limitations of the compound, these studies have been performed mainly in an in vitro model and the molecular mechanism of the berberine anticancer activity has already been studied in detail. However, several clinical trials are currently being carried out on its antitumor activity. Currently, the first phase of the study is underway to prevent colorectal cancer in patients with ulcerative colitis in remission [23].

Berberine is cytotoxic to cancer cell lines and this activity depends on the dose and time. The therapeutic window of berberine, in most cases, is narrow and depends also on the type of cells that are treated [7]. For example, the cell viability of leukemic cell lines obtained by Och et al. was in the rage of $80 \mu \mathrm{M}-250 \mu \mathrm{M}$, with $80 \mu \mathrm{M}$ to CCRF/CEM; $80,15 \mu \mathrm{M}$ to J45.01; 90,45 $\mu \mathrm{M}$ to HL-60; $110,05 \mu \mathrm{M}$ to HL-60/MX1; 225,15 $\mu \mathrm{M}$ to CEM/C1; and $240,45 \mu \mathrm{M}$ to U266B1. The HL-60/MX2 cells exposed to berberine did not fall below $50 \%$, despite their exposure to the maximum concentrations possible that could be obtained in the in vitro experiment $(250 \mu \mathrm{M})$ and in this case, the dose of IC50 could not be determined for this line due to the poor cytotoxicity of the compound [100].

Berberine results in the downregulation of the 33 genes involved in the cell cycle and cell differentiation. It is time- and dose-dependent [101]. Berberine arrests human cancer cells in the G1 phase in low concentrations. At high concentrations, it arrests the cell cycle in the G2/M phase [96,102]. Berberine inhibits the cell cycle in the G1 phase by the up-regulation of the B-cell translocation gene 2 . This proliferation regulatory gene is induced by the p53 protein. The cell cycle arrest in the $\mathrm{G} 2 / \mathrm{M}$ phase by berberine is p53-independent [102-104]. The phase arrest G0/G1 was reported in bladder cancer cell lines BIU-87 and T24, and the lymphocytic leukemia cell line L1210, after its exposure to berberine $[105,106]$. The colon cancer cells' exposure to berberine from caused a phase cell cycle arrest of G0/G1 with the down-regulation of the anti-apoptotic gene BCL2 and was concentration-dependent [107-109]. One of the targets for berberine-induced cell cycle 
arrest is cyclins. Cyclin D1 was down-regulated after its exposure to berberine in the G1 cell cycle phase [102]. The lower expression of cyclin B1 and the increased expression of Wee1 can arrest tumor cells in the G1 and G2 phases after their exposure to berberine [102,110]. In MDA-MB-231 and MCF-7 breast cancer cells, after their exposure to berberine, G0/G1 arrest, which is possibly due to a decrease in the level of the cell cycle regulatory protein cyclin B1. This effect was dose dependent [102]. The cell cycle arrest in the G2/M phase by berberine is dependent on the REV3 gene [111]. The inhibition of the cell cycle in the G2/M phase after its exposure to berberine has also been described in colorectal cancer cells of the SW480 line [112].

Apoptosis is one of the most extensively researched and documented berberineinduced processes. The proapoptotic properties of berberine have been confirmed after its exposure to alkaloids and the induction of biochemical events, such as a decrease in mitochondrial membrane potency, caspase activation, poly-(ADP-ribose)-polymerase (PARP) breakdown, or the release of cytochrome $\mathrm{C}$ or Bc12 proteins [113]. Berberine acts as a proapoptotic in tumor cells by its up-regulation of pro-apoptotic genes and its down-regulation of anti-apoptotic genes [97,100]. In leukemic cells exposed to berberine, changes in gene expression showed that even a low cytotoxic dose of berberine increased the expression of caspase genes CASP3, CASP8, and CASP9, as well as the pro-apoptotic genes BIK, BAX, and BAK1 with a simultaneous down-regulation of the expression of the anti-apoptotic genes BNIP1, BNIP3, BCL2, and BCL2L2 [100]. Moreover, in HL-60 [114], U937, and B16 lines [115], the activation of protein caspase-3 and -9 , an increase in the Bcl2-associated $X$ protein (Bax), and a decrease in the Bcl-2 protein level after its exposure to berberine were reported [114]. By investigating the pro-apoptotic activity of berberine, we can also find that other pro-apoptotic proteins are involved in the apoptosis signaling pathways, such as p53, retinoblastoma protein, caspase-8, Fas receptor (death receptor)/FasL (Fas ligand), ATM (serine/threonine kinase), BID (BH3 interacting domain death agonist, a pro-apoptotic member of the family of Bcl-2 proteins), and TNF. The levels of these proteins have been reported to increase after their exposure to berberine, while the levels of Bcl-X, Survivin (an antiapoptotic protein), c-IAP1 (an inhibitor of the apoptosis protein), and XIAP (the X-linked inhibitor of the apoptosis protein) decreased after their exposure to berberine. Berberine was also shown to regulate apoptotic proteins through an increase in the level of reactive oxygen species, one of the key apoptosis regulation agents $[40,97,116]$.

The next target in berberine-induced apoptosis is the death receptors (DR), known as a tumor necrosis factor-related apoptosis-inducing ligand receptor (TRAIL). TRIAL has a great potential in cancer treatment. It induces apoptosis by binding to the aforementioned death receptors, i.e., DR4 and DR5, and it induces tumor cell death. TRAIL selectively induces apoptosis, and the development of resistance (partial or complete) limits its use. Berberine acts synergistically with TRAIL. Furthermore, it sensitizes cancer cells with resistance to TRAIL. In the TRAIL-sensitive MDA-MB-231 breast cancer cell line, and the TRAIL-resistant MDA-MB-468 human breast cancer cell line, berberine acts synergistically with TRAIL but it also sensitizes resistant cells, which was confirmed with the markers of the process: caspase-3, PARP 9 Poly (ADP-ribose) polymerase 1 cleavage, and p53. Moreover, in the $4 \mathrm{~T} 1$ breast cancer cell line, despite its moderate cytotoxicity, berberine, in combination with antiDR5, inhibited the primary growth and reduced its metastasis to the lungs $[110,117]$.

There are scientific reports on the effects of berberine on mitogen-activated kinases (MAP or MAPK) that are involved in the direction of cell responses. They regulate processes important in carcinogenesis, for example, apoptosis, mitosis, gene expression, proliferation, and differentiation [96]. Berberine modulates mitogen-activated protein kinase signaling pathways, such as the p38 MAPK extracellular signal-regulated kinase $1 / 2(E R K 1 / 2)$ and the JNK pathways.

The modulation of these pathways is noteworthy in the search for new potential anticancer drugs, and the effects depend on the cell type. Berberine activates MAPK in human colon cancer cells [118], human hepatoma cells (HepG2), and in non-small cell 
lung cancer cells [38,39]. In turn, in human HeLa cervical carcinoma cells, berberine enhances the phosphorylation of JNK and ERK1/2 but it inhibits the phosphorylation of p38 MAPK [119]. Furthermore, berberine reduces the phosphorylation of p38 MAPK, JNK, and ERK1/2 in gastric cancer cells [41]. This JNK/p38 MAPK signaling pathway is disrupted in many types of cancer [120]. Berberine was shown to suppress cancer cell invasion and migration in the gastric cancer SNU-1 cell line by blocking the JNK/p38 signaling pathway [40]. More precisely, berberine acts on MAPK through the impact of microRNA that inhibits the translation of certain proteins, whose dysfunction plays a role in the formation of cancer. The levels of these proteins are correlated with the tissue factor TF, which contributes to tumor metastasis and has been shown to activate signaling cascades, including MAPK. Apoptosis through the miR-19a/TF/MAPK signaling pathway has been described after exposure to berberine in human lung cancer A549 cells. Berberine lowers the level of TF and raises the level of miR-19a, thus activating MAPK signaling that leads to the apoptosis of cancer cells [39]. The cyclin-dependent kinase inhibitor p21 (CIP1/WAF1), which is involved in apoptosis, cell cycle control, DNA replication, and cell differentiation [52] is linked with the human protein Forkhead box O3 (FOXO3a) and p53 in control of cancer cell growth [121-123]. FOXO3a is a transcription factor that belongs to the family of transcription factors with tumor suppressor activities. It is regulated by the phosphatidylinositol 3-kinase/Akt signaling pathway, and its growth factor receptor-induced activation is connected to cell cycle arrest [124] and apoptosis [125] and, in general, with tumor suppression. It is known that the inhibition of FOXO3a causes tumor progression [126]. In non-small cell lung cancer, berberine induces apoptosis and inhibits proliferation by activating the $\mathrm{p} 38 \alpha$ MAPK signaling pathway, resulting in increased levels of FOXO3a and p53 and the induction of the cell cycle inhibitor p21 (CIP1/WAF1) [38,126].

Berberine also acts against transcription factor 1 (AP-1). AP-1 is closely related to neoplastic transformation. It consists of complexes comprising of the following families of DNA-binding proteins: the Jun family (JunD, c-Jun, JunB, and v-Jun), the Fos family (Fra-1, c-Fos, FosB, and Fra-2), the Maf family (MafA, c-Maf, MafB, MafG/F/K, and Nrl) and the binding of ATF/cyclic AMP-responsive elements (b-ATF, ATF1-4, ATF-6, and ATFx), which play a key role in proliferation, apoptosis, and inflammation. AP-1 activity is regulated by UV radiation, infections, cell stress, growth factors, and cytokines [127]. Extrinsic carcinogens induce an increase in AP1 activity [128]. Many human tumors overexpress the Jun family [129-131]. This overexpression has been described in aggressive lymphomas [132,133] and in breast cancer [131]. On the other hand, the increased expression of c-Fos is described in endometrial cancer and osteosarcoma, while the decreased expression of c-Fos is observed in ovarian and gastric cancer [134]. AP-1 activation has been described to depend on the type of extrinsic stimulus and the cellular condition. For example, in the HepG2 line hepatoma cells after their exposure to berberine, the AP-1 protein was inhibited $[99,135]$. On the other hand, the inhibition of Lewis lung cancer metastasis from the mediastinal lymph nodes to the lung parenchyma was described through the activation of the AP-1 protein after the oral administration of berberine [136]. The oral administration of berberine also decreased the expression of the C-fos proto-oncogene [110]. In conclusion, the influence of berberine on the AP1 protein family is dependent on the cell type, and needs further investigation.

In berberine, anticancer activity is also based on the influence on $\beta$-catenin. Mutations and the overexpression of $\beta$-catenin are associated with cancers, such as colorectal carcinoma, endometrial cancer, breast cancer, and ovarian tumors. In colon cancer cells, the expression of its mRNA is down-regulated by berberine. The alkaloid efficiently inhibits the nuclear level of $\beta$-catenin [137], regulates $\beta$-catenin negatively, and stimulates the expression of the adenomatous polyposis coli protein [96,110].

The metabolism of fats and lipids plays a role in the malignancies of the digestive system and is one of the advantageous mechanisms of the consequences of berberine in the metabolic syndrome. Berberine induces apoptosis in gastric cancer cells through the 
reduction of fatty acid accumulation and the reduction of FABP expression [138]. Berberine also down-regulates lipogenic enzymes, which are key in colon cancer. Berberine affects the SREBP-1 cleavage activating protein-1/sterol receptor element binding protein-1 pathway (SCAP/SREBP-1) that drives lipogenesis, inhibiting the pathway. As a result, the downregulation of lipogenic enzymes is observed, leading to the suppression of lipid synthesis linked to cell proliferation through the Wnt/ $\beta$-catenin pathway [109]. Furthermore, the influence on JNK kinases plays a role in the anticancer and chemopreventive activity of berberine, in terms of the influence on lipid metabolism and its role in cancer development $[139,140]$. Current data from clinical trials indicate the chemopreventive potential of berberine in relation to neoplasms, such as colorectal cancer developing from adenomas and the prevention of adenoma.

Colon adenomas are precancerous lesions that develop into colon cancer. The removal of precancerous lesions is currently established to prevent colorectal cancer. Due to the high rate of recurrence of colorectal adenomas in patients after polypectomy, chemopreventive agents are sought to reduce the risk of the recurrence of colorectal adenomas. In patients with colorectal adenomas, after a complete polypectomy, receiving berberine twice daily was effective and safe. The risk of the recurrence of colorectal adenoma was reduced, making berberine an option for chemoprevention in patients after polypectomy [15].

Importantly, for oncological patients, berberine mitigates the effects of radiation therapy. In patients with lymphoma and cervical cancer, the mitigation of the effects of radiation therapy was described, and in patients with non-small cell lung cancer, berberine protected lung cells from damage induced by ionized radiation [141]. Berberine selectively sensitized tumor cells to ionizing radiation in patients with glioma [142].

\section{Berberine in Mental Disorders within the Metabolic Syndrome}

As mentioned above, chronic stress, anxiety, depression, and personality disorders may lead to the development of the metabolic syndrome, and may be caused by it. Recent studies have shown that the prevalence of mental disorders, including severe conditions, such as schizophrenia, bipolar disorders, and depression is two to three times higher within the course of the metabolic syndrome, compared to the general population [143-145]. On the other hand, impaired glucose metabolism and dyslipidemia could have pathoplastic effects on psychiatric disorders [146]. Although certain antidiabetic drugs are helpful in controlling weight gain and elevated glucose levels during antipsychotic therapy, most conventional psychiatric drugs stimulate appetite receptors, which can lead to the development or progression of the metabolic syndrome [147]. Berberine administration in rats has been shown to significantly prevent olanzapine-induced weight gain and modulate the expression of many key genes that control energy expenditure. Berberine has also been shown to change the activity of biogenic amine neurotransmitters involved in the pathogenesis of the anti-psychotic drug-induced metabolic syndrome [148-158].

Researchers suggest that berberine acts as antidepressant; however, no clinical models have been conducted so far. Several studies in animal models suggested that berberine administration could help to promote optimal mental health by increasing the level of brain neurotransmitters, such as dopamine, serotonin, and norepinephrine, which are necessary to maintain proper brain functioning and a positive mood [52,159-161]. This effect results from the ability of berberine to inhibit monoamine oxidase activity, the main target of many antidepressant drugs $[162,163]$. Berberine, like other antidepressant drugs, affects sigma receptor 1 . Studies also show that berberine can act as an antidepressant through the nuclear factor kappa-light-chain-enhancer of activated B-cells (NF-kB) signaling pathway, which is activated by oxidative stress.

Recent findings reveal that the antidepressant effects of berberine result from the activation of the 5-HT2 receptor by its impact on the brain-derived neurotrophic factor-cAMP response element, the binding protein, and the eukaryotic elongation factor 2 pathways. These well-known antidepressant pathways are crucial for the antidepressant action of 
drugs. Berberine acts by increasing neurotrophic factor levels and restores the decreased levels of its mRNA [96,164].

Berberine has also been shown to be active in neurodegenerative disorders [165,166]. Recent studies have shown that it has a protective effect on the central nervous system $[167,168]$ and that it exerts a neuroprotective effect by regulating the early immune activation of peripheral lymphocytes and immunotolerance in vivo [52]. However, this is not fully understood, and there are reports on berberine exacerbating neurodegeneration [159]. Furthermore, berberine significantly decreases kynurenine production, which, when increased, is metabolized to neurotoxic compounds (for example, quinolinic acid), and influences glutamatergic neurotransmission $[96,164]$. Berberine has also been described to inhibit the effects of rewards after the abuse of drugs, such as cocaine, morphine, and ethanol. It proceeds through the down-regulation of tyrosine hydroxylase expression or other mechanisms $[165,169,170]$. Berberine easily crosses the blood-brain barrier after its systemic administration, which increases its potential in the treatment of neurological diseases, but it needs further clinical investigation $[165,166]$.

Current clinical trials of berberine in patients with schizophrenia are based on the hypothesis that berberine, as an adjuvant, can control weight gain and other metabolic symptoms associated with antipsychotic therapy. Studies are carried out to determine whether an adjuvant therapy with berberine limits weight gain in patients with schizophrenia who developed the metabolic syndrome $[16,17,23]$.

\section{Summary}

Berberine is an alkaloid with strong pharmacological activities that are currently receiving great interest, and it is believed to be effective in patients with the metabolic syndrome in terms of risk factors, its course, and the consequences of the disease. Berberine prevents the development of atherosclerosis, DM2, and cardiovascular disorders. Furthermore, it has been shown to be administered preventively and it decreases the risk of developing the metabolic syndrome due to its neuroprotective and antidepressant activities. Berberine is also effective in the case of dyslipidemia, liver cirrhosis due to non-alcoholic or alcoholic steatohepatitis, infertility, and ovulation disorders. However, the most important and widely studied property of berberine is its anticancer activity, which is crucial, since the implication of the metabolic syndrome is a significantly increased risk of certain malignant neoplasms. Despite intensive research, there is still much confusion about the detailed effects of berberine. An example is the fact that the impact of berberine on certain pharmacological parameters is gender-specific, which requires further research. Zhao et al. suggests that berberine has different effects on testosterone in men than in women. This concerns women with PCOS, who tend to have higher testosterone, and concludes that the effects could be different in women with normal endocrine parameters. As such, a further examination of the effects of berberine on endocrine factors, such as sex hormone binding globulin, are needed.

Currently, several clinical trials with metabolic syndrome are being conducted with regard to the risk factors, course, and consequences of the disease, with outcomes expected in the near future. The most intensively investigated are colorectal adenomas, the spectrum of schizophrenia, other psychotic disorders, prediabetes (impaired fasting glucose and impaired glucose tolerance), stable coronary artery disease, diabetes mellitus, chronic kidney disease, non-alcoholic steatohepatitis, hypertension, endothelial dysfunction, blood pressure, and chronic kidney disease (Table 2). 
Table 2. Active clinical trials with berberine on the metabolic syndrome and its corresponding diseases based on clinicaltrials.gov (accessed on 10 Fabruary 2022).

\begin{tabular}{|c|c|c|c|c|}
\hline Title & Conditions & Status & Phase & Measures \\
\hline $\begin{array}{l}\text { A Research of berberine } \\
\text { hydrochloride to } \\
\text { prevent colorectal } \\
\text { adenomas in patients } \\
\text { with previous } \\
\text { colorectal cancer }\end{array}$ & $\begin{array}{l}\text { Colorectal } \\
\text { adenomas }\end{array}$ & Recruiting & $\begin{array}{l}\text { Phase } 2 \\
\text { Phase } 3\end{array}$ & $\begin{array}{l}\text { - } \quad \text { Cumulative colorectal adenoma } \\
\text { - Cumulative numbers or diameters of } \\
\text { new colorectal adenomas }\end{array}$ \\
\hline $\begin{array}{l}\text { Comparison of } \\
\text { berberine and } \\
\text { metformin for the } \\
\text { treatment of MS in } \\
\text { schizophrenia patients }\end{array}$ & $\begin{array}{l}\text { Schizophrenia } \\
\text { Metabolic } \\
\text { syndrome }\end{array}$ & Recruiting & Phase 4 & $\begin{array}{ll}\text { - } & \text { Fasting blood glucose } \\
\text { - } & \text { Triglyceride } \\
\text { - } & \text { High-density lipoprotein } \\
\text { - } & \text { Waist circumference } \\
\text { - } & \text { Blood pressure including systolic and } \\
\text { - } & \text { diastolic pressure } \\
\text { - } & \text { Tody mass index cholesterol } \\
\text { - } & \text { CRP } \\
\text { - } & \text { Interleukin-1, interleukin-6, TNF- } \alpha\end{array}$ \\
\hline $\begin{array}{l}\text { Effect of berberine } \\
\text { versus metformin on } \\
\text { glycemic control, } \\
\text { insulin sensitivity, and } \\
\text { insulin secretion in } \\
\text { prediabetes }\end{array}$ & $\begin{array}{l}\text { Prediabetes impaired } \\
\text { Fasting glucose } \\
\text { impaired Glucose } \\
\text { tolerance }\end{array}$ & $\begin{array}{l}\text { Active, not } \\
\text { recruiting }\end{array}$ & Phase 4 & $\begin{array}{ll}\text { - } & \text { Fasting glucose levels } \\
\text { - } & \text { Postprandial glucose levels } \\
\text { - } & \text { Glycosylated hemoglobin } \\
\text { - } & \text { Total insulin secretion } \\
\text { - } & \text { First phase of insulin secretion } \\
\text { - } & \text { Insulin sensitivity } \\
\text { - } & \text { Body weight } \\
\text { - } & \text { Body mass index } \\
\text { - } & \text { Body fat percentage } \\
\text { - } & \text { Waist circumference }\end{array}$ \\
\hline $\begin{array}{l}\text { Effect of berberine for } \\
\text { endothelial function } \\
\text { and intestinal } \\
\text { microflora in patients } \\
\text { with coronary artery } \\
\text { disease }\end{array}$ & $\begin{array}{l}\text { Stable coronaryartery } \\
\text { diseasePercutaneous } \\
\text { coronary intervention }\end{array}$ & $\begin{array}{l}\text { Active, not } \\
\text { recruiting }\end{array}$ & $\begin{array}{l}\text { Phase } 1 \\
\text { Phase } 2\end{array}$ & $\begin{array}{ll}\text { - } & \text { Endothelial function } \\
\text { - } & \text { Gut microbiome } \\
\text { - } & \text { Fecal metabolomics profile } \\
\text { - } & \text { Blood lipid levels } \\
\text { - } & \text { Inflammatory factor levels } \\
\text { - } & \text { Blood glucose levels }\end{array}$ \\
\hline $\begin{array}{l}\text { Berberine prevents } \\
\text { contrast-induced } \\
\text { nephropathy in } \\
\text { patients with diabetes }\end{array}$ & $\begin{array}{l}\text { Diabetes } \\
\text { mellitus Chronic } \\
\text { kidney disease }\end{array}$ & Recruiting & Phase 4 & $\begin{array}{l}\text { - } \quad \text { Contrast-induced nephropathy } \\
\text { - } \quad \text { Major adverse renal events }\end{array}$ \\
\hline $\begin{array}{l}\text { Berberine as adjuvant } \\
\text { treatment for } \\
\text { schizophrenia patients }\end{array}$ & $\begin{array}{c}\text { Schizophrenia } \\
\text { Schizophrenia } \\
\text { spectrum and } \\
\text { other psychotic } \\
\text { disorders } \\
\text { Metabolic syndrome X }\end{array}$ & Recruiting & $\begin{array}{l}\text { Phase } 2 \\
\text { Phase } 3\end{array}$ & $\begin{array}{ll}\text { - } & \text { Weight gain } \\
\text { - } & \text { Body mass index } \\
\text { - } & \text { Waist circumference } \\
\text { - } & \text { Triglycerides } \\
\text { - } & \text { Total cholesterol } \\
\text { - } & \text { High-density lipoprotein } \\
\text { - } & \text { Low-density lipoprotein } \\
\text { - } & \text { Fasting glucose } \\
\text { - } & \text { Insulin }\end{array}$ \\
\hline $\begin{array}{l}\text { Evaluating the } \\
\text { tolerability and effects } \\
\text { of berberine on major } \\
\text { metabolic biomarkers: } \\
\text { a pilot study }\end{array}$ & $\begin{array}{l}\text { Metabolic } \\
\text { syndrome }\end{array}$ & Recruiting & $\begin{array}{c}\text { Not } \\
\text { Applicable }\end{array}$ & $\begin{array}{ll}\text { - } & \text { LDL cholesterol } \\
\text { - } & \text { Hemoglobin A1c } \\
\text { - } & \text { Adverse events }\end{array}$ \\
\hline
\end{tabular}


Table 2. Cont.

\begin{tabular}{|c|c|c|c|c|}
\hline Title & Conditions & Status & Phase & Measures \\
\hline $\begin{array}{l}\text { Efficacy and safety of } \\
\text { berberine in } \\
\text { non-alcoholic } \\
\text { steatohepatitis }\end{array}$ & $\begin{array}{l}\text { Non-alcoholic } \\
\text { steatohepatitis }\end{array}$ & Recruiting & Phase 4 & $\begin{array}{l}\text { Histologic features of non-alcoholic } \\
\text { steatohepatitis } \\
\text { - } \\
\text { Improvement in the composites of } \\
\text { NAFLD activity scores for steatosis, } \\
\text { lobular inflammation, and } \\
\text { hepatocellular ballooning } \\
\text { - } \text { Improvement in liver histological } \\
\text { fibrosis staging } \\
\text { - } \\
\text { - } \\
\text { - } \\
\text { Bnthropometric measures } \\
\text { - }\end{array}$ \\
\hline $\begin{array}{l}\text { Study on the efficacy } \\
\text { and gut microbiota of } \\
\text { berberine and } \\
\text { probiotics in patients } \\
\text { with newly diagnosed } \\
\text { type } 2 \text { diabetes }\end{array}$ & Type 2 diabetes & $\begin{array}{l}\text { Active, not } \\
\text { recruiting }\end{array}$ & Phase 3 & $\begin{array}{ll}\text { - } & \text { HbA1c } \\
\text { - } & \text { Gut microbiome } \\
\text { - } & \text { Fasting glucose levels } \\
\text { - } & \text { 2-h postprandial glucose levels } \\
\text { - } & \text { Fasting insulin levels } \\
\text { - } & \text { 2-h postprandial insulin levels } \\
\text { - } & \text { Serum triglycerides } \\
\text { - } & \text { Serum total cholesterol } \\
\text { - } & \text { Serum HDL-C }\end{array}$ \\
\hline $\begin{array}{l}\text { Effect of berberine } \\
\text { hydrochloride on blood } \\
\text { pressure and vascular } \\
\text { endothelial function in } \\
\text { patients With } \\
\text { hypertension }\end{array}$ & $\begin{array}{l}\text { Hypertension } \\
\text { Endothelial } \\
\text { dysfunction } \\
\text { Blood pressure }\end{array}$ & Recruting & Phase 4 & $\begin{array}{ll}\text { - } & \text { Blood pressure } \\
\text { - } & \text { Brachial ankle pulse wave velocity } \\
\text { - } & \text { Blood pressure } \\
\text { dilation }\end{array}$ \\
\hline $\begin{array}{l}\text { Effect of berberine on } \\
\text { metabolic syndrome, } \\
\text { efficacy and safety in } \\
\text { combination with } \\
\text { antiretroviral therapy } \\
\text { in PLWH }\end{array}$ & $\begin{array}{l}\text { Metabolic syndrome } \\
\text { HIV-1-infection } \\
\text { Glucose intolerance }\end{array}$ & $\begin{array}{l}\text { Not yet } \\
\text { recruiting }\end{array}$ & Phase 3 & $\begin{array}{l}\text { - Insulin resistance } \\
\text { - } \quad \text { Measurement of total cholesterol, } \\
\text { HDL, LDL, triglycerides } \\
\text { - Weight gain or loss measured by } \\
\text { kilograms } \\
\text { - Level of pro-inflammatory cytokines }\end{array}$ \\
\hline $\begin{array}{l}\text { Berberine prevents } \\
\text { contrast-induced } \\
\text { nephropathy in } \\
\text { patients with diabetes }\end{array}$ & $\begin{array}{c}\text { Diabetes mellitus } \\
\text { Chronic kidney disease }\end{array}$ & Recruiting & Phase 4 & $\begin{array}{l}\text { - } \quad \text { Contrast-induced nephropathy } \\
\text { - } \quad \text { Increase in serum creatinine } \\
\text { - }\end{array}$ \\
\hline $\begin{array}{l}\text { Evaluating the } \\
\text { tolerability and effects } \\
\text { of berberine on major } \\
\text { metabolic biomarkers: } \\
\text { a pilot study }\end{array}$ & Metabolic syndrome & Recruiting & $\begin{array}{c}\text { Not } \\
\text { Applicable }\end{array}$ & $\begin{array}{l}\text { - } \quad \text { Change in LDL Cholesterol } \\
\text { - } \quad \text { Change in Hemoglobin A1c } \\
\text { - }\end{array}$ \\
\hline $\begin{array}{l}\text { Efficacy and safety of } \\
\text { berberine in } \\
\text { non-alcoholic } \\
\text { steatohepatitis }\end{array}$ & $\begin{array}{l}\text { Non-alcoholic } \\
\text { steatohepatitis }\end{array}$ & Recruiting & Phase 4 & $\begin{array}{ll}\text { - } & \text { Histologic features of non-alcoholic } \\
\text { steatohepatitis } \\
\text { - } & \text { Liver histological fibrosis staging } \\
\text { - } & \text { BMI } \\
\text { - } & \text { Blood biochemistry } \\
\text { - } & \text { Liver fat content } \\
\text { - } & \text { Serum cytokeratin } 18\end{array}$ \\
\hline
\end{tabular}


Table 2. Cont.

\begin{tabular}{|c|c|c|c|c|}
\hline Title & Conditions & Status & Phase & Measures \\
\hline $\begin{array}{l}\text { Study to determine the } \\
\text { effect of synbiotics in } \\
\text { patients with } \\
\text { pre-diabetes }\end{array}$ & Pre-diabetes & Recruiting & $\begin{array}{c}\text { Not } \\
\text { Applicable }\end{array}$ & $\begin{array}{l}\text { - } \quad \text { Blood glucose levels } \\
\text { - } \\
\text { and butyratic impact of metabolic rheostat } \\
\text { - Gut hormones/incretins (including } \\
\text { insulin, C-peptide, glucagon, CCK, } \\
\text { GLP-1, GIP, and PYY) } \\
\text { - Impact of metabolic rheostat and } \\
\text { butyrate ultra on food addiction and } \\
\text { cravings }\end{array}$ \\
\hline
\end{tabular}

The new derivatives and formulations of berberine are a crucial challenge for scientists, as a low bioavailability and poor pharmacokinetic parameters of berberine still remain an obstacle in its potential usage. The development of new formulations and derivatives with similar biological activities, that are not limited by low pharmacological parameters, seem to be the most important targets. Compounds, based on berberine, that are effective at lower concentrations and have stronger biological activities are currently being intensively investigated. The latest articles provide information on the significant relationship between its structure and activity. New derivatives exhibit similar parameters of biological activity and are promising for further research.

Author Contributions: Conceptualization, A.O., R.P. and R.N.; methodology, A.O.; software, R.P.; validation, M.O., R.P. and D.P.; formal analysis, R.N. and M.O.; investigation, A.O., R.P. and R.N.; resources, A.O., R.P. and R.N.; data curation, A.O., R.N., M.O., R.P. and D.P.; writing-original draft preparation, A.O.; writing-review and editing, A.O., R.P. and R.N.; supervision, R.N.; project administration, R.P. and D.P.; funding acquisition, R.P. and D.P. All authors have read and agreed to the published version of the manuscript.

Funding: This research received no external funding.

Institutional Review Board Statement: Not applicable.

Informed Consent Statement: Not applicable.

Data Availability Statement: Not applicable.

Conflicts of Interest: The authors declare no conflict of interest.

\section{References}

1. $\quad$ Eckel, R.H.; Grundy, S.M.; Zimmet, P.Z. The Metabolic Syndrome. Lancet 2005, 365, 1415-1428. [CrossRef]

2. Dietrich, P.; Hellerbrand, C. Non-Alcoholic Fatty Liver Disease, Obesity and the Metabolic Syndrome. Best Pract. Res. Clin. Gastroenterol. 2014, 28, 637-653. [CrossRef] [PubMed]

3. Sherling, D.H.; Perumareddi, P.; Hennekens, C.H. Metabolic Syndrome. J. Cardiovasc. Pharmacol. Ther. 2017, 22, 365-367. [CrossRef] [PubMed]

4. De la Iglesia, R.; Loria-Kohen, V.; Zulet, M.A.; Martinez, J.A.; Reglero, G.; Ramirez de Molina, A. Dietary Strategies Implicated in the Prevention and Treatment of Metabolic Syndrome. Int. J. Mol. Sci. 2016, 17, 1877. [CrossRef] [PubMed]

5. Ganguli, R.; Strassnig, M. Prevention of Metabolic Syndrome in Serious Mental Illness. Psychiatr. Clin. 2011, 34, 109-125. [CrossRef] [PubMed]

6. Zarich, S.W. Metabolic Syndrome, Diabetes and Cardiovascular Events: Current Controversies and Recommendations. Minerva Cardioangiol. 2006, 54, 195-214.

7. Och, A.; Podgórski, R.; Nowak, R. Biological Activity of Berberine-A Summary Update. Toxins 2020, 12, 713. [CrossRef]

8. Zhao, J.V.; Yeung, W.-F.; Chan, Y.-H.; Vackova, D.; Leung, J.Y.Y.; Ip, D.K.M.; Zhao, J.; Ho, W.-K.; Tse, H.-F.; Schooling, C.M. Effect of Berberine on Cardiovascular Disease Risk Factors: A Mechanistic Randomized Controlled Trial. Nutrients 2021, 13, 2550. [CrossRef]

9. Gonnelli, S.; Caffarelli, C.; Stolakis, K.; Cuda, C.; Giordano, N.; Nuti, R. Efficacy and Tolerability of a Nutraceutical Combination (Red Yeast Rice, Policosanols, and Berberine) in Patients with Low-Moderate Risk Hypercholesterolemia: A Double-Blind, Placebo-Controlled Study. Curr. Ther. Res. 2015, 77, 1-6. [CrossRef] 
10. Affuso, F.; Mercurio, V.; Ruvolo, A.; Pirozzi, C.; Micillo, F.; Carlomagno, G.; Grieco, F.; Fazio, S. A Nutraceutical Combination Improves Insulin Sensitivity in Patients with Metabolic Syndrome. World J. Cardiol. 2012, 4, 77-83. [CrossRef]

11. Pirro, M.; Mannarino, M.R.; Ministrini, S.; Fallarino, F.; Lupattelli, G.; Bianconi, V.; Bagaglia, F.; Mannarino, E. Effects of a Nutraceutical Combination on Lipids, Inflammation and Endothelial Integrity in Patients with Subclinical Inflammation: A Randomized Clinical Trial. Sci. Rep. 2016, 6, 23587. [CrossRef] [PubMed]

12. Spigoni, V.; Aldigeri, R.; Antonini, M.; Micheli, M.M.; Fantuzzi, F.; Fratter, A.; Pellizzato, M.; Derlindati, E.; Zavaroni, I.; Bonadonna, R.C.; et al. Effects of a New Nutraceutical Formulation (Berberine, Red Yeast Rice and Chitosan) on Non-HDL Cholesterol Levels in Individuals with Dyslipidemia: Results from a Randomized, Double Blind, Placebo-Controlled Study. Int. J. Mol. Sci. 2017, 18, 1498. [CrossRef] [PubMed]

13. Solà, R.; Valls, R.-M.; Puzo, J.; Calabuig, J.-R.; Brea, A.; Pedret, A.; Moriña, D.; Villar, J.; Millán, J.; Anguera, A. Effects of Poly-Bioactive Compounds on Lipid Profile and Body Weight in a Moderately Hypercholesterolemic Population with Low Cardiovascular Disease Risk: A Multicenter Randomized Trial. PLoS ONE 2014, 9, e101978. [CrossRef] [PubMed]

14. Trimarco, V.; Izzo, R.; Stabile, E.; Rozza, F.; Santoro, M.; Manzi, M.V.; Serino, F.; Schiattarella, G.G.; Esposito, G.; Trimarco, B. Effects of a New Combination of Nutraceuticals with Morus Alba on Lipid Profile, Insulin Sensitivity and Endotelial Function in Dyslipidemic Subjects. A Cross-over, Randomized, Double-Blind Trial. High Blood Press. Cardiovasc. Prev. 2015, $22,149-154$. [CrossRef] [PubMed]

15. Chen, Y.-X.; Gao, Q.-Y.; Zou, T.-H.; Wang, B.-M.; Liu, S.-D.; Sheng, J.-Q.; Ren, J.-L.; Zou, X.-P.; Liu, Z.-J.; Song, Y.-Y.; et al. Berberine versus Placebo for the Prevention of Recurrence of Colorectal Adenoma: A Multicentre, Double-Blinded, Randomised Controlled Study. Lancet Gastroenterol. Hepatol. 2020, 5, 267-275. [CrossRef]

16. Li, M.; Liu, Y.; Qiu, Y.; Zhang, J.; Zhang, Y.; Zhao, Y.; Jia, Q.; Li, J. The Effect of Berberine Adjunctive Treatment on Glycolipid Metabolism in Patients with Schizophrenia: A Randomized, Double-Blind, Placebo-Controlled Clinical Trial. Psychiatry Res. 2021, 300, 113899. [CrossRef]

17. Zhang, L.-S.; Zhang, J.-H.; Feng, R.; Jin, X.-Y.; Yang, F.-W.; Ji, Z.-C.; Zhao, M.-Y.; Zhang, M.-Y.; Zhang, B.-L.; Li, X.-M. Efficacy and Safety of Berberine Alone or Combined with Statins for the Treatment of Hyperlipidemia: A Systematic Review and Meta-Analysis of Randomized Controlled Clinical Trials. Am. J. Chin. Med. 2019, 47, 751-767. [CrossRef]

18. Zhao, M.-M.; Lu, J.; Li, S.; Wang, H.; Cao, X.; Li, Q.; Shi, T.-T.; Matsunaga, K.; Chen, C.; Huang, H.; et al. Berberine Is an Insulin Secretagogue Targeting the KCNH6 Potassium Channel. Nat. Commun. 2021, 12, 5616. [CrossRef]

19. Yin, J.; Xing, H.; Ye, J. Efficacy of Berberine in Patients with Type 2 Diabetes Mellitus. Metabolism 2008, 57, 712-717. [CrossRef]

20. Wang, H.; Zhu, C.; Ying, Y.; Luo, L.; Huang, D.; Luo, Z. Metformin and Berberine, Two Versatile Drugs in Treatment of Common Metabolic Diseases. Oncotarget 2017, 9, 10135-10146. [CrossRef]

21. Wu, N.; Sarna, L.K.; Siow, Y.L.; O, K. Regulation of Hepatic Cholesterol Biosynthesis by Berberine during Hyperhomocysteinemia. Am. J. Physiol.-Regul. Integr. Comp. Physiol. 2011, 300, R635-R643. [CrossRef] [PubMed]

22. Wang, Y.; Yi, X.; Ghanam, K.; Zhang, S.; Zhao, T.; Zhu, X. Berberine Decreases Cholesterol Levels in Rats through Multiple Mechanisms, Including Inhibition of Cholesterol Absorption. Metabolism 2014, 63, 1167-1177. [CrossRef] [PubMed]

23. Home-ClinicalTrials.Gov. Available online: https://clinicaltrials.gov/ (accessed on 22 January 2022).

24. An, Y.; Sun, Z.; Zhang, Y.; Liu, B.; Guan, Y.; Lu, M. The Use of Berberine for Women with Polycystic Ovary Syndrome Undergoing IVF Treatment. Clin. Endocrinol. 2014, 80, 425-431. [CrossRef] [PubMed]

25. Ko, B.-S.; Choi, S.B.; Park, S.K.; Jang, J.S.; Kim, Y.E.; Park, S. Insulin Sensitizing and Insulinotropic Action of Berberine from Cortidis Rhizoma. Biol. Pharm. Bull. 2005, 28, 1431-1437. [CrossRef]

26. Chang, W.; Zhang, M.; Li, J.; Meng, Z.; Wei, S.; Du, H.; Chen, L.; Hatch, G.M. Berberine Improves Insulin Resistance in Cardiomyocytes via Activation of 5'-Adenosine Monophosphate-Activated Protein Kinase. Metabolism 2013, 62, $1159-1167$. [CrossRef]

27. Hu, Y.; Davies, G.E. Berberine Inhibits Adipogenesis in High-Fat Diet-Induced Obesity Mice. Fitoterapia 2010, 81, 358-366. [CrossRef]

28. Yu, Y.; Liu, L.; Wang, X.; Liu, X.; Liu, X.; Xie, L.; Wang, G. Modulation of Glucagon-like Peptide-1 Release by Berberine: In Vivo and in Vitro Studies. Biochem. Pharmacol. 2010, 79, 1000-1006. [CrossRef]

29. Pan, G.-Y.; Huang, Z.-J.; Wang, G.-J.; Fawcett, J.P.; Liu, X.-D.; Zhao, X.-C.; Sun, J.-G.; Xie, Y.-Y. The Antihyperglycaemic Activity of Berberine Arises from a Decrease of Glucose Absorption. Planta Med. 2003, 69, 632-636. [CrossRef]

30. Ye, M.; Fu, S.; Pi, R.; He, F. Neuropharmacological and Pharmacokinetic Properties of Berberine: A Review of Recent Research. J. Pharm. Pharmacol. 2009, 61, 831-837. [CrossRef]

31. Wei, X.; Zhu, L.; Wang, C. Efficacy and Safety of Berberine in Patients with Type 2 Diabetes Mellitus: A Meta-Analysis. Chin. Herb. Med. 2015, 7, 344-353. [CrossRef]

32. Li, C.; Guan, X.-M.; Wang, R.-Y.; Xie, Y.-S.; Zhou, H.; Ni, W.-J.; Tang, L.-Q. Berberine Mitigates High Glucose-Induced Podocyte Apoptosis by Modulating Autophagy via the MTOR/P70S6K/4EBP1 Pathway. Life Sci. 2020, 243, 117277. [CrossRef] [PubMed]

33. Zhang, Y.; Sun, J.; Zhang, Y.-J.; Chai, Q.-Y.; Zhang, K.; Ma, H.-L.; Wu, X.-K.; Liu, J.-P. The Effect of Berberine on Insulin Resistance in Women with Polycystic Ovary Syndrome: Detailed Statistical Analysis Plan (SAP) for a Multicenter Randomized Controlled Trial. Trials 2016, 17, 512. [CrossRef] [PubMed] 
34. Li, Y.; Ma, H.; Zhang, Y.; Kuang, H.; Ng, E.H.Y.; Hou, L.; Wu, X. Effect of Berberine on Insulin Resistance in Women with Polycystic Ovary Syndrome: Study Protocol for a Randomized Multicenter Controlled Trial. Trials 2013, 14, 226. [CrossRef] [PubMed]

35. Dahlberg, C.J.; Ou, J.J.; Babish, J.G.; Lamb, J.J.; Eliason, S.; Brabazon, H.; Gao, W.; Kaadige, M.R.; Tripp, M.L. A 13-Week Low Glycemic Load Diet and Lifestyle Modification Program Combining Low Glycemic Load Protein Shakes and Targeted Nutraceuticals Improved Weight Loss and Cardio-Metabolic Risk Factors. Can. J. Physiol. Pharmacol. 2017, 95, 1414-1425. [CrossRef]

36. Kumar, R.; Awasthi, M.; Sharma, A.; Padwad, Y.; Sharma, R. Berberine Induces Dose-Dependent Quiescence and Apoptosis in A549 Cancer Cells by Modulating Cell Cyclins and Inflammation Independent of MTOR Pathway. Life Sci. 2020, $244,117346$. [CrossRef]

37. Bogoyevitch, M.A.; Boehm, I.; Oakley, A.; Ketterman, A.J.; Barr, R.K. Targeting the JNK MAPK Cascade for Inhibition: Basic Science and Therapeutic Potential. Biochim. Biophys. Acta 2004, 1697, 89-101. [CrossRef]

38. Zheng, F.; Tang, Q.; Wu, J.; Zhao, S.; Liang, Z.; Li, L.; Wu, W.; Hann, S. P38 $\alpha$ MAPK-Mediated Induction and Interaction of FOXO3a and P53 Contribute to the Inhibited-Growth and Induced-Apoptosis of Human Lung Adenocarcinoma Cells by Berberine. J. Exp. Clin. Cancer Res. 2014, 33, 36. [CrossRef]

39. Chen, Q.; Shi, J.; Ding, Z.; Xia, Q.; Zheng, T.; Ren, Y.; Li, M.; Fan, L. Berberine Induces Apoptosis in Non-Small-Cell Lung Cancer Cells by Upregulating MiR-19a Targeting Tissue Factor. Cancer Manag. Res. 2019, 11, 9005-9015. [CrossRef]

40. Wang, Y.; Zhou, M.; Shang, D. Berberine Inhibits Human Gastric Cancer Cell Growth via Deactivation of P38/JNK Pathway, Induction of Mitochondrial-Mediated Apoptosis, Caspase Activation and NF-KB Inhibition. J. Balk. Union Oncol. 2020, 25, 314-318.

41. Li, H.-L.; Wu, H.; Zhang, B.-B.; Shi, H.-L.; Wu, X.-J. MAPK Pathways Are Involved in the Inhibitory Effect of Berberine Hydrochloride on Gastric Cancer MGC 803 Cell Proliferation and IL-8 Secretion in Vitro and in Vivo. Mol. Med. Rep. 2016, 14, 1430-1438. [CrossRef]

42. Wu, X.-K.; Wang, Y.-Y.; Liu, J.-P.; Hou, L.-H.; Gao, Y.-Q.; Du, S.-M.; Yan, Y.; Zhang, J.-F.; Xue, H.-Y.; Li, W.-L.; et al. Letrozole, Berberine, or a Combination for Infertility in Chinese Women with Polycystic Ovary Syndrome: A Multicentre, Randomised, Double-Blind, Placebo-Controlled Trial. Lancet 2015, 386, S70. [CrossRef]

43. Cicero, A.F.G.; Reggi, A.; Parini, A.; Morbini, M.; Rosticci, M.; Grandi, E.; Borghi, C. Berberine and Monacolin Effects on the Cardiovascular Risk Profile of Women with Oestroprogestin-Induced Hypercholesterolemia. High Blood Press. Cardiovasc. Prev. 2014, 21, 221-226. [CrossRef]

44. Zhang, S.; Zhou, J.; Gober, H.-J.; Leung, W.T.; Wang, L. Effect and Mechanism of Berberine against Polycystic Ovary Syndrome. Biomed. Pharmacother. 2021, 138, 111468. [CrossRef] [PubMed]

45. Wu, X.-K.; Wang, Y.-Y.; Liu, J.-P.; Liang, R.-N.; Xue, H.-Y.; Ma, H.-X.; Shao, X.-G.; Ng, E.H.Y.; Hou, L.-H.; Wang, Y.-Y.; et al. Randomized Controlled Trial of Letrozole, Berberine, or a Combination for Infertility in the Polycystic Ovary Syndrome. Fertil. Steril. 2016, 106, 757-765.e1. [CrossRef] [PubMed]

46. Imanshahidi, M.; Hosseinzadeh, H. Pharmacological and Therapeutic Effects of Berberis Vulgaris and Its Active Constituent, Berberine. Phytother. Res. 2008, 22, 999-1012. [CrossRef] [PubMed]

47. Derosa, G.; D'Angelo, A.; Vanelli, A.; Maffioli, P. An Evaluation of a Nutraceutical with Berberine, Curcumin, Inositol, Banaba and Chromium Picolinate in Patients with Fasting Dysglycemia. Diabetes Metab. Syndr. Obes. 2020, 13, 653-661. [CrossRef] [PubMed]

48. Dandona, P.; Aljada, A.; Bandyopadhyay, A. Inflammation: The Link between Insulin Resistance, Obesity and Diabetes. Trends Immunol. 2004, 25, 4-7. [CrossRef]

49. Li, X.-Y.; Zhao, Z.-X.; Huang, M.; Feng, R.; He, C.-Y.; Ma, C.; Luo, S.-H.; Fu, J.; Wen, B.-Y.; Ren, L.; et al. Effect of Berberine on Promoting the Excretion of Cholesterol in High-Fat Diet-Induced Hyperlipidemic Hamsters. J. Transl. Med. 2015, 13, 278. [CrossRef]

50. Wang, Y.; Zidichouski, J.A. Update on the Benefits and Mechanisms of Action of the Bioactive Vegetal Alkaloid Berberine on Lipid Metabolism and Homeostasis. Cholesterol 2018, 2018, 7173920. [CrossRef]

51. Barrios, V.; Escobar, C.; Cicero, A.F.G.; Burke, D.; Fasching, P.; Banach, M.; Bruckert, E. A Nutraceutical Approach (Armolipid Plus) to Reduce Total and LDL Cholesterol in Individuals with Mild to Moderate Dyslipidemia: Review of the Clinical Evidence. Atheroscler. Suppl. 2017, 24,1-15. [CrossRef]

52. Song, B.; Tang, X.; Wang, X.; Huang, X.; Ye, Y.; Lu, X.; Wei, X.; Zeng, Y. Bererine Induces Peripheral Lymphocytes Immune Regulations to Realize Its Neuroprotective Effects in the Cerebral Ischemia/Reperfusion Mice. Cell. Immunol. 2012, 276, 91-100. [CrossRef]

53. Wang, L.; Peng, L.; Wei, G.; Ge, H. Therapeutic Effects of Berberine Capsule on Patients with Mild Hyperlipidemia. Zhongguo Zhong Xi Yi Jie He Za Zhi 2016, 36, 681-684. [PubMed]

54. Cereda, E.; Cappello, S.; Caraccia, M.; Turri, A.; Masi, S.; Nappi, R.; Caccialanza, R. SUN-PO004: Nutraceutical Intervention with Berberine, Chlorogenic Acid and Tocotrienols for Menopause-Associated Dyslipidemia: A Pilot, Single-ARM Trial. Clin. Nutr. 2019, 38, S60. [CrossRef]

55. Yan, H.-M.; Xia, M.-F.; Wang, Y.; Chang, X.-X.; Yao, X.-Z.; Rao, S.-X.; Zeng, M.-S.; Tu, Y.-F.; Feng, R.; Jia, W.-P.; et al. Efficacy of Berberine in Patients with Non-Alcoholic Fatty Liver Disease. PLoS ONE 2015, 10, e0134172. [CrossRef] 
56. Kuno, T.; Hirayama-Kurogi, M.; Ito, S.; Ohtsuki, S. Effect of Intestinal Flora on Protein Expression of Drug-Metabolizing Enzymes and Transporters in the Liver and Kidney of Germ-Free and Antibiotics-Treated Mice. Mol. Pharm. 2016, 13, 2691-2701. [CrossRef] [PubMed]

57. Han, J.; Lin, H.; Huang, W. Modulating Gut Microbiota as an Anti-Diabetic Mechanism of Berberine. Med. Sci. Monit. 2011, 17, RA164-RA167. [CrossRef] [PubMed]

58. Cani, P.D.; Van Hul, M.; Lefort, C.; Depommier, C.; Rastelli, M.; Everard, A. Microbial Regulation of Organismal Energy Homeostasis. Nat. Metab. 2019, 1, 34-46. [CrossRef] [PubMed]

59. Ning, G. Decade in Review-Type 2 Diabetes Mellitus: At the Centre of Things. Nat. Rev. Endocrinol. 2015, 11, 636-638. [CrossRef]

60. Manichanh, C.; Rigottier-Gois, L.; Bonnaud, E.; Gloux, K.; Pelletier, E.; Frangeul, L.; Nalin, R.; Jarrin, C.; Chardon, P.; Marteau, P.; et al. Reduced Diversity of Faecal Microbiota in Crohn's Disease Revealed by a Metagenomic Approach. Gut 2006, 55, 205-211. [CrossRef]

61. Louis, P.; Hold, G.L.; Flint, H.J. The Gut Microbiota, Bacterial Metabolites and Colorectal Cancer. Nat. Rev. Microbiol. 2014, 12, 661-672. [CrossRef]

62. Bloomgarden, Z. Diabetes and Branched-Chain Amino Acids: What Is the Link? J. Diabetes. 2018, 10, 350-352. [CrossRef] [PubMed]

63. Priyadarshini, M.; Wicksteed, B.; Schiltz, G.E.; Gilchrist, A.; Layden, B.T. SCFA Receptors in Pancreatic $\beta$ Cells: Novel Diabetes Targets? Trends Endocrinol. Metab. 2016, 27, 653-664. [CrossRef] [PubMed]

64. Sonnenburg, E.D.; Sonnenburg, J.L. Starving Our Microbial Self: The Deleterious Consequences of a Diet Deficient in MicrobiotaAccessible Carbohydrates. Cell Metab. 2014, 20, 779-786. [CrossRef] [PubMed]

65. Turnbaugh, P.J.; Hamady, M.; Yatsunenko, T.; Cantarel, B.L.; Duncan, A.; Ley, R.E.; Sogin, M.L.; Jones, W.J.; Roe, B.A.; Affourtit, J.P.; et al. A Core Gut Microbiome in Obese and Lean Twins. Nature 2009, 457, 480-484. [CrossRef] [PubMed]

66. Bäckhed, F.; Manchester, J.K.; Semenkovich, C.F.; Gordon, J.I. Mechanisms Underlying the Resistance to Diet-Induced Obesity in Germ-Free Mice. Proc. Natl. Acad. Sci. USA 2007, 104, 979-984. [CrossRef] [PubMed]

67. Larsen, N.; Vogensen, F.K.; Van Den Berg, F.W.J.; Nielsen, D.S.; Andreasen, A.S.; Pedersen, B.K.; Al-Soud, W.A.; Sørensen, S.J.; Hansen, L.H.; Jakobsen, M. Gut Microbiota in Human Adults with Type 2 Diabetes Differs from Non-Diabetic Adults. PLoS ONE 2010, 5, e9085. [CrossRef]

68. Sun, R.; Yang, N.; Kong, B.; Cao, B.; Feng, D.; Yu, X.; Ge, C.; Huang, J.; Shen, J.; Wang, P.; et al. Orally Administered Berberine Modulates Hepatic Lipid Metabolism by Altering Microbial Bile Acid Metabolism and the Intestinal FXR Signaling Pathway. Mol. Pharmacol. 2017, 91, 110-122. [CrossRef]

69. Xie, W.; Gu, D.; Li, J.; Cui, K.; Zhang, Y. Effects and Action Mechanisms of Berberine and Rhizoma Coptidis on Gut Microbes and Obesity in High-Fat Diet-Fed C57BL/6J Mice. PLoS ONE 2011, 6, e24520. [CrossRef]

70. Gao, Z.; Li, Q.; Wu, X.; Zhao, X.; Zhao, L.; Tong, X. New Insights into the Mechanisms of Chinese Herbal Products on Diabetes: A Focus on the "Bacteria-Mucosal Immunity-Inflammation-Diabetes" Axis. J. Immunol. Res. 2017, 2017, 1813086. [CrossRef]

71. Cui, H.-X.; Hu, Y.-N.; Li, J.-W.; Yuan, K.; Guo, Y. Preparation and Evaluation of Antidiabetic Agents of Berberine Organic Acid Salts for Enhancing the Bioavailability. Molecules 2019, 24, 103. [CrossRef]

72. Habtemariam, S. Berberine Pharmacology and the Gut Microbiota: A Hidden Therapeutic Link. Pharmacol. Res. 2020, 155, 104722. [CrossRef] [PubMed]

73. Chae, S.-H.; Jeong, I.-H.; Choi, D.-H.; Oh, J.-W.; Ahn, Y.-J. Growth-Inhibiting Effects of Coptis Japonica Root-Derived Isoquinoline Alkaloids on Human Intestinal Bacteria. J. Agric. Food Chem. 1999, 47, 934-938. [CrossRef]

74. Guo, Y.; Zhang, Y.; Huang, W.; Selwyn, F.P.; Klaassen, C.D. Dose-Response Effect of Berberine on Bile Acid Profile and Gut Microbiota in Mice. BMC Complement Altern. Med. 2016, 16, 394. [CrossRef] [PubMed]

75. Tian, Y.; Cai, J.; Gui, W.; Nichols, R.G.; Koo, I.; Zhang, J.; Anitha, M.; Patterson, A.D. Berberine Directly Affects the Gut Microbiota to Promote Intestinal Farnesoid X Receptor Activation. Drug Metab. Dispos. 2019, 47, 86-93. [CrossRef] [PubMed]

76. Lynch, C.J.; Adams, S.H. Branched-Chain Amino Acids in Metabolic Signalling and Insulin Resistance. Nat. Rev. Endocrinol. 2014, 10, 723-736. [CrossRef] [PubMed]

77. Yue, S.-J.; Liu, J.; Wang, A.-T.; Meng, X.-T.; Yang, Z.-R.; Peng, C.; Guan, H.-S.; Wang, C.-Y.; Yan, D. Berberine Alleviates Insulin Resistance by Reducing Peripheral Branched-Chain Amino Acids. Am. J. Physiol.-Endocrinol. Metab. 2018, 316, E73-E85. [CrossRef]

78. Zhang, X.; Zhao, Y.; Zhang, M.; Pang, X.; Xu, J.; Kang, C.; Li, M.; Zhang, C.; Zhang, Z.; Zhang, Y.; et al. Structural Changes of Gut Microbiota during Berberine-Mediated Prevention of Obesity and Insulin Resistance in High-Fat Diet-Fed Rats. PLoS ONE 2012, 7, e42529. [CrossRef] [PubMed]

79. Wang, Y.; Shou, J.-W.; Li, X.-Y.; Zhao, Z.-X.; Fu, J.; He, C.-Y.; Feng, R.; Ma, C.; Wen, B.-Y.; Guo, F.; et al. Berberine-Induced Bioactive Metabolites of the Gut Microbiota Improve Energy Metabolism. Metabolism 2017, 70, 72-84. [CrossRef]

80. Gu, Y.; Wang, X.; Li, J.; Zhang, Y.; Zhong, H.; Liu, R.; Zhang, D.; Feng, Q.; Xie, X.; Hong, J.; et al. Analyses of Gut Microbiota and Plasma Bile Acids Enable Stratification of Patients for Antidiabetic Treatment. Nat. Commun. 2017, 8, 1785. [CrossRef]

81. Sun, L.; Xie, C.; Wang, G.; Wu, Y.; Wu, Q.; Wang, X.; Liu, J.; Deng, Y.; Xia, J.; Chen, B.; et al. Gut Microbiota and Intestinal FXR Mediate the Clinical Benefits of Metformin. Nat. Med. 2018, 24, 1919-1929. [CrossRef]

82. Zhang, Y.; Gu, Y.; Ren, H.; Wang, S.; Zhong, H.; Zhao, X.; Ma, J.; Gu, X.; Xue, Y.; Huang, S.; et al. Gut Microbiome-Related Effects of Berberine and Probiotics on Type 2 Diabetes (the PREMOTE Study). Nat. Commun. 2020, 11, 5015. [CrossRef] [PubMed]

83. Chiang, J.Y.L. Bile Acids: Regulation of Synthesis. J. Lipid Res. 2009, 50, 1955-1966. [CrossRef] [PubMed] 
84. Maslowski, K.M.; Vieira, A.T.; Ng, A.; Kranich, J.; Sierro, F.; Yu, D.; Schilter, H.C.; Rolph, M.S.; Mackay, F.; Artis, D.; et al. Regulation of Inflammatory Responses by Gut Microbiota and Chemoattractant Receptor GPR43. Nature 2009, 461, 1282-1286. [CrossRef]

85. Sun, Y.; Jin, C.; Zhang, X.; Jia, W.; Le, J.; Ye, J. Restoration of GLP-1 Secretion by Berberine Is Associated with Protection of Colon Enterocytes from Mitochondrial Overheating in Diet-Induced Obese Mice. Nutr. Diabetes 2018, 8, 53. [CrossRef] [PubMed]

86. Zhang, X.; Zhao, Y.; Xu, J.; Xue, Z.; Zhang, M.; Pang, X.; Zhang, X.; Zhao, L. Modulation of Gut Microbiota by Berberine and Metformin during the Treatment of High-Fat Diet-Induced Obesity in Rats. Sci. Rep. 2015, 5, 14405. [CrossRef]

87. Zhang, W.; Xu, J.-H.; Yu, T.; Chen, Q.-K. Effects of Berberine and Metformin on Intestinal Inflammation and Gut Microbiome Composition in Db/Db Mice. Biomed. Pharmacother. 2019, 118, 109131. [CrossRef]

88. Vidrine, K.; Ye, J.; Martin, R.J.; McCutcheon, K.L.; Raggio, A.M.; Pelkman, C.; Durham, H.A.; Zhou, J.; Senevirathne, R.N.; Williams, C.; et al. Resistant Starch from High Amylose Maize (HAM-RS2) and Dietary Butyrate Reduce Abdominal Fat by a Different Apparent Mechanism. Obesity 2014, 22, 344-348. [CrossRef]

89. Qin, J.; Li, Y.; Cai, Z.; Li, S.; Zhu, J.; Zhang, F.; Liang, S.; Zhang, W.; Guan, Y.; Shen, D.; et al. A Metagenome-Wide Association Study of Gut Microbiota in Type 2 Diabetes. Nature 2012, 490, 55-60. [CrossRef]

90. Reddy, P.; Lent-Schochet, D.; Ramakrishnan, N.; McLaughlin, M.; Jialal, I. Metabolic Syndrome Is an Inflammatory Disorder: A Conspiracy between Adipose Tissue and Phagocytes. Clin. Chim. Acta 2019, 496, 35-44. [CrossRef]

91. Gurung, P.; Moussa, K.; Adams-Huet, B.; Devaraj, S.; Jialal, I. Increased Mast Cell Abundance in Adipose Tissue of Metabolic Syndrome: Relevance to the Proinflammatory State and Increased Adipose Tissue Fibrosis. Am. J. Physiol. Endocrinol. Metab. 2019, 316, E504-E509. [CrossRef]

92. Moussa, K.; Gurung, P.; Adams-Huet, B.; Devaraj, S.; Jialal, I. Increased Eosinophils in Adipose Tissue of Metabolic Syndrome. J. Diabetes Complicat. 2019, 33, 535-538. [CrossRef] [PubMed]

93. Jialal, I.; Devaraj, S. Subcutaneous Adipose Tissue Biology in Metabolic Syndrome. Horm. Mol. Biol. Clin. Investig. 2018, 33. [CrossRef] [PubMed]

94. Shim, K.; Gulhar, R.; Jialal, I. Exploratory Metabolomics of Nascent Metabolic Syndrome. J. Diabetes Complicat. 2019, 33, $212-216$. [CrossRef]

95. Bremer, A.A.; Jialal, I. Adipose Tissue Dysfunction in Nascent Metabolic Syndrome. J. Obes. 2013, 2013, 393192. [CrossRef]

96. Ayati, S.H.; Fazeli, B.; Momtazi-borojeni, A.A.; Cicero, A.F.G.; Pirro, M.; Sahebkar, A. Regulatory Effects of Berberine on MicroRNome in Cancer and Other Conditions. Crit. Rev. Oncol. Hematol. 2017, 116, 147-158. [CrossRef] [PubMed]

97. Su, Y.-H.; Tang, W.-C.; Cheng, Y.-W.; Sia, P.; Huang, C.-C.; Lee, Y.-C.; Jiang, H.-Y.; Wu, M.-H.; Lai, I.-L.; Lee, J.-W.; et al. Targeting of Multiple Oncogenic Signaling Pathways by Hsp90 Inhibitor Alone or in Combination with Berberine for Treatment of Colorectal Cancer. Biochim. Biophys. Acta (BBA)-Mol. Cell Res. 2015, 1853, 2261-2272. [CrossRef] [PubMed]

98. Hamsa, T.P.; Kuttan, G. Antiangiogenic Activity of Berberine Is Mediated through the Downregulation of Hypoxia-Inducible Factor-1, VEGF, and Proinflammatory Mediators. Drug Chem. Toxicol. 2012, 35, 57-70. [CrossRef]

99. Fukuda, K.; Hibiya, Y.; Mutoh, M.; Koshiji, M.; Akao, S.; Fujiwara, H. Inhibition by Berberine of Cyclooxygenase-2 Transcriptional Activity in Human Colon Cancer Cells. J. Ethnopharmacol. 1999, 66, 227-233. [CrossRef]

100. Och, A.; Zalewski, D.; Komsta, Ł.; Kołodziej, P.; Kocki, J.; Bogucka-Kocka, A. Cytotoxic and Proapoptotic Activity of Sanguinarine, Berberine, and Extracts of Chelidonium majus L. and Berberis Thunbergii DC. toward Hematopoietic Cancer Cell Lines. Toxins 2019, 11, 485. [CrossRef]

101. Palmieri, A.; Scapoli, L.; Iapichino, A.; Mercolini, L.; Mandrone, M.; Poli, F.; Giannì, A.B.; Baserga, C.; Martinelli, M. Berberine and Tinospora cordifolia Exert a Potential Anticancer Effect on Colon Cancer Cells by Acting on Specific Pathways. Int. J. Immunopathol. Pharmacol. 2019, 33. [CrossRef]

102. Liu, D.; Meng, X.; Wu, D.; Qiu, Z.; Luo, H. A Natural Isoquinoline Alkaloid With Antitumor Activity: Studies of the Biological Activities of Berberine. Front. Pharmacol. 2019, 10, 9. [CrossRef] [PubMed]

103. Yang, M.; Yang, Y.; Cui, H.; Guan, Z.; Yang, Y.; Zhang, H.; Chen, X.; Zhu, H.; Yang, X.; Cai, J.; et al. The Natural Compound Gambogic Acid Radiosensitizes Nasopharyngeal Carcinoma Cells under Hypoxic Conditions. Tumori 2016, 102, 135-143. [CrossRef] [PubMed]

104. Li, L.; Wang, X.; Sharvan, R.; Gao, J.; Qu, S. Berberine Could Inhibit Thyroid Carcinoma Cells by Inducing Mitochondrial Apoptosis, G0/G1 Cell Cycle Arrest and Suppressing Migration via PI3K-AKT and MAPK Signaling Pathways. Biomed. Pharmacother. 2017, 95, 1225-1231. [CrossRef] [PubMed]

105. Jantová, S.; Čipák, L.; Čerňáková, M.; Košt'álová, D. Effect of Berberine on Proliferation, Cell Cycle and Apoptosis in HeLa and L1210 Cells. J. Pharm. Pharmacol. 2003, 55, 1143-1149. [CrossRef] [PubMed]

106. Yan, K.; Zhang, C.; Feng, J.; Hou, L.; Yan, L.; Zhou, Z.; Liu, Z.; Liu, C.; Fan, Y.; Zheng, B.; et al. Induction of G1 Cell Cycle Arrest and Apoptosis by Berberine in Bladder Cancer Cells. Eur. J. Pharmacol. 2011, 661, 1-7. [CrossRef]

107. Gong, C.; Hu, X.; Xu, Y.; Yang, J.; Zong, L.; Wang, C.; Zhu, J.; Li, Z.; Lu, D. Berberine Inhibits Proliferation and Migration of Colorectal Cancer Cells by Downregulation of GRP78. Anti-Cancer Drugs 2020, 31, 141-149. [CrossRef] [PubMed]

108. Dai, W.; Mu, L.; Cui, Y.; Li, Y.; Chen, P.; Xie, H.; Wang, X. Long Non-coding RNA CASC2 Enhances Berberine-induced Cytotoxicity in Colorectal Cancer Cells by Silencing BCL2. Mol. Med. Rep. 2019, 20, 995-1006. [CrossRef] 
109. Liu, Y.; Hua, W.; Li, Y.; Xian, X.; Zhao, Z.; Liu, C.; Zou, J.; Li, J.; Fang, X.; Zhu, Y. Berberine Suppresses Colon Cancer Cell Proliferation by Inhibiting the SCAP/SREBP-1 Signaling Pathway-Mediated Lipogenesis. Biochem. Pharmacol. 2020, $174,113776$. [CrossRef]

110. Farooqi, A.A.; Qureshi, M.Z.; Khalid, S.; Attar, R.; Martinelli, C.; Sabitaliyevich, U.Y.; Nurmurzayevich, S.B.; Taverna, S.; Poltronieri, P.; Xu, B. Regulation of Cell Signaling Pathways by Berberine in Different Cancers: Searching for Missing Pieces of an Incomplete Jig-Saw Puzzle for an Effective Cancer Therapy. Cancers 2019, 11, 478. [CrossRef]

111. Hu, X.; Wu, X.; Huang, Y.; Tong, Q.; Takeda, S.; Qing, Y. Berberine Induces Double-Strand DNA Breaks in Rev3 Deficient Cells. Mol. Med. Rep. 2014, 9, 1883-1888. [CrossRef]

112. Chidambara Murthy, K.N.; Jayaprakasha, G.K.; Patil, B.S. The Natural Alkaloid Berberine Targets Multiple Pathways to Induce Cell Death in Cultured Human Colon Cancer Cells. Eur. J. Pharmacol. 2012, 688, 14-21. [CrossRef] [PubMed]

113. Kalaiarasi, A.; Anusha, C.; Sankar, R.; Rajasekaran, S.; John Marshal, J.; Muthusamy, K.; Ravikumar, V. Plant Isoquinoline Alkaloid Berberine Exhibits Chromatin Remodeling by Modulation of Histone Deacetylase To Induce Growth Arrest and Apoptosis in the A549 Cell Line. J. Agric. Food Chem. 2016, 64, 9542-9550. [CrossRef] [PubMed]

114. Lin, C.-C.; Kao, S.-T.; Chen, G.-W.; Ho, H.-C.; Chung, J.-G. Apoptosis of Human Leukemia HL-60 Cells and Murine Leukemia WEHI-3 Cells Induced by Berberine through the Activation of Caspase-3. Anticancer Res. 2006, 26, 227-242. [PubMed]

115. Letašiová, S.; Jantová, S.; Čipák, L.; Múčková, M. Berberine-Antiproliferative Activity in Vitro and Induction of Apoptosis/Necrosis of the U937 and B16 Cells. Cancer Lett. 2006, 239, 254-262. [CrossRef]

116. Sanna, L.; Marchesi, I.; Melone, M.A.B.; Bagella, L. The Role of Enhancer of Zeste Homolog 2: From Viral Epigenetics to the Carcinogenesis of Hepatocellular Carcinoma. J. Cell. Physiol. 2018, 233, 6508-6517. [CrossRef] [PubMed]

117. Refaat, A.; Abdelhamed, S.; Yagita, H.; Inoue, H.; Yokoyama, S.; Hayakawa, Y.; Saiki, I. Berberine Enhances Tumor Necrosis Factor-related Apoptosis-inducing Ligand-mediated Apoptosis in Breast Cancer. Oncol. Lett. 2013, 6, 840-844. [CrossRef]

118. Hsu, W.-H.; Hsieh, Y.-S.; Kuo, H.-C.; Teng, C.-Y.; Huang, H.-I.; Wang, C.-J.; Yang, S.-F.; Liou, Y.-S.; Kuo, W.-H. Berberine Induces Apoptosis in SW620 Human Colonic Carcinoma Cells through Generation of Reactive Oxygen Species and Activation of JNK/P38 MAPK and FasL. Arch. Toxicol. 2007, 81, 719-728. [CrossRef]

119. Lu, B.; Hu, M.; Liu, K.; Peng, J. Cytotoxicity of Berberine on Human Cervical Carcinoma HeLa Cells through Mitochondria, Death Receptor and MAPK Pathways, and in-Silico Drug-Target Prediction. Toxicology In Vitro 2010, 24, 1482-1490. [CrossRef]

120. Zarubin, T.; Han, J. Activation and Signaling of the P38 MAP Kinase Pathway. Cell Res. 2005, 15, 11-18. [CrossRef]

121. Renault, V.M.; Thekkat, P.U.; Hoang, K.L.; White, J.L.; Brady, C.A.; Kenzelmann Broz, D.; Venturelli, O.S.; Johnson, T.M.; Oskoui, P.R.; Xuan, Z.; et al. The Pro-Longevity Gene FoxO3 Is a Direct Target of the P53 Tumor Suppressor. Oncogene 2011, 30, 3207-3221. [CrossRef]

122. Macleod, K.F.; Sherry, N.; Hannon, G.; Beach, D.; Tokino, T.; Kinzler, K.; Vogelstein, B.; Jacks, T. P53-Dependent and Independent Expression of P21 during Cell Growth, Differentiation, and DNA Damage. Genes Dev. 1995, 9, 935-944. [CrossRef] [PubMed]

123. Hauck, L.; Harms, C.; Grothe, D.; An, J.; Gertz, K.; Kronenberg, G.; Dietz, R.; Endres, M.; von Harsdorf, R. Critical Role for FoxO3a-Dependent Regulation of P21CIP1/WAF1 in Response to Statin Signaling in Cardiac Myocytes. Circ. Res. 2007, 100, 50-60. [CrossRef] [PubMed]

124. Schmidt, M.; Fernandez de Mattos, S.; van der Horst, A.; Klompmaker, R.; Kops, G.J.P.L.; Lam, E.W.-F.; Burgering, B.M.T.; Medema, R.H. Cell Cycle Inhibition by FoxO Forkhead Transcription Factors Involves Downregulation of Cyclin D. Mol. Cell. Biol. 2002, 22, 7842-7852. [CrossRef] [PubMed]

125. Brunet, A.; Bonni, A.; Zigmond, M.J.; Lin, M.Z.; Juo, P.; Hu, L.S.; Anderson, M.J.; Arden, K.C.; Blenis, J.; Greenberg, M.E. Akt Promotes Cell Survival by Phosphorylating and Inhibiting a Forkhead Transcription Factor. Cell 1999, 96, 857-868. [CrossRef]

126. Yang, J.-Y.; Zong, C.S.; Xia, W.; Yamaguchi, H.; Ding, Q.; Xie, X.; Lang, J.-Y.; Lai, C.-C.; Chang, C.-J.; Huang, W.-C.; et al. ERK Promotes Tumorigenesis by Inhibiting FOXO3a via MDM2-Mediated Degradation. Nat. Cell Biol. 2008, 10, 138-148. [CrossRef]

127. Gazon, H.; Barbeau, B.; Mesnard, J.-M.; Peloponese, J.-M.J. Hijacking of the AP-1 Signaling Pathway during Development of ATL. Front. Microbiol. 2018, 8, 2686. [CrossRef]

128. Abate, C.; Curran, T. Encounters with Fos and Jun on the Road to AP-1. Semin. Cancer Biol. 1990, 1, $19-26$.

129. Neyns, B.; Vermeij, J.; Bourgain, C.; Vandamme, B.; Amfo, K.; Lissens, W.; DeSutter, P.; Hooghe-Peters, E.; DeGrève, J. Expression of the Jun Family of Genes in Human Ovarian Cancer and Normal Ovarian Surface Epithelium. Oncogene 1996, 12, $1247-1257$.

130. Langer, S.; Singer, C.F.; Hudelist, G.; Dampier, B.; Kaserer, K.; Vinatzer, U.; Pehamberger, H.; Zielinski, C.; Kubista, E.; Schreibner, M. Jun and Fos Family Protein Expression in Human Breast Cancer: Correlation of Protein Expression and Clinicopathological Parameters. Eur. J. Gynaecol. Oncol. 2006, 27, 345-352.

131. Kharman-Biz, A.; Gao, H.; Ghiasvand, R.; Zhao, C.; Zendehdel, K.; Dahlman-Wright, K. Expression of Activator Protein-1 (AP-1) Family Members in Breast Cancer. BMC Cancer 2013, 13, 441. [CrossRef]

132. Drakos, E.; Leventaki, V.; Schlette, E.J.; Jones, D.; Lin, P.; Jeffrey Medeiros, L.; Rassidakis, G.Z. C-Jun Expression and Activation Are Restricted to CD30+ Lymphoproliferative Disorders. Am. J. Surg. Pathol. 2007, 31, 447-453. [CrossRef]

133. Mao, X.; Orchard, G.; Russell-Jones, R.; Whittaker, S. Abnormal Activator Protein 1 Transcription Factor Expression in CD30Positive Cutaneous Large-Cell Lymphomas. Br. J. Dermatol. 2007, 157, 914-921. [CrossRef] [PubMed]

134. Tulchinsky, E. Fos Family Members: Regulation, Structure and Role in Oncogenic Transformation. Histol. Histopathol. 2000. [CrossRef] 
135. Lin, J.G.; Chung, J.G.; Wu, L.T.; Chen, G.W.; Chang, H.L.; Wang, T.F. Effects of Berberine on Arylamine N-Acetyltransferase Activity in Human Colon Tumor Cells. Am. J. Chin. Med. 1999, 27, 265-275. [CrossRef] [PubMed]

136. Mitani, N.; Murakami, K.; Yamaura, T.; Ikeda, T.; Saiki, I. Inhibitory Effect of Berberine on the Mediastinal Lymph Node Metastasis Produced by Orthotopic Implantation of Lewis Lung Carcinoma. Cancer Lett. 2001, 165, 35-42. [CrossRef]

137. Yu, F.-S.; Yang, J.-S.; Lin, H.-J.; Yu, C.-S.; Tan, T.-W.; Lin, Y.-T.; Lin, C.-C.; Lu, H.-F.; Chung, J.-G. Berberine Inhibits WEHI-3 Leukemia Cells In Vivo. In Vivo 2007, 21, 407-412.

138. Li, L.; Peng, Z.; Hu, Q.; Xu, L.; Zou, X.; Yu, Y.; Huang, D.; Yi, P. Berberine Suppressed Tumor Growth through Regulating Fatty Acid Metabolism and Triggering Cell Apoptosis via Targeting FABPs. Evid.-Based Complementary Altern. Med. 2020, 2020, 6195050. [CrossRef]

139. Sun, Y.; Wang, W.; Tong, Y. Berberine Inhibits Proliferative Ability of Breast Cancer Cells by Reducing Metadherin. Med. Sci. Monit. 2019, 25, 9058-9066. [CrossRef]

140. Zhao, L.; Zhang, C. Berberine Inhibits MDA-MB-231 Cells by Attenuating Their Inflammatory Responses. Biomed. Res. Int. 2020, 2020, 3617514. [CrossRef]

141. Liu, Y.; Yu, H.; Zhang, C.; Cheng, Y.; Hu, L.; Meng, X.; Zhao, Y. Protective Effects of Berberine on Radiation-Induced Lung Injury via Intercellular Adhesion Molecular-1 and Transforming Growth Factor-Beta-1 in Patients with Lung Cancer. Eur. J. Cancer 2008, 44, 2425-2432. [CrossRef]

142. Yount, G.; Qian, Y.; Moore, D.; Basila, D.; West, J.; Aldape, K.; Arvold, N.; Shalev, N.; Haas-Kogan, D. Berberine Sensitizes Human Glioma Cells, but Not Normal Glial Cells, to Ionizing Radiation in Vitro. J. Exp. Ther. Oncol. 2004, 4, 137-143. [PubMed]

143. Ohaeri, J.U.; Akanji, A.O. Metabolic Syndrome in Severe Mental Disorders. Metab. Syndr. Relat. Disord. 2011, 9, 91-98. [CrossRef] [PubMed]

144. Lyra e Silva, N.D.M.; Lam, M.P.; Soares, C.N.; Munoz, D.P.; Milev, R.; De Felice, F.G. Insulin Resistance as a Shared Pathogenic Mechanism Between Depression and Type 2 Diabetes. Front. Psychiatry 2019, 10, 57. [CrossRef] [PubMed]

145. Penninx, B.W.J.H.; Lange, S.M.M. Metabolic Syndrome in Psychiatric Patients: Overview, Mechanisms, and Implications. Dialogues Clin. Neurosci. 2018, 20, 63-73.

146. Salvi, V.; Hajek, T. Editorial: Brain-Metabolic Crossroads in Severe Mental Disorders—Focus on Metabolic Syndrome. Front. Psychiatry 2019, 10, 492. [CrossRef] [PubMed]

147. Bhuvaneswar, C.G.; Baldessarini, R.J.; Harsh, V.L.; Alpert, J.E. Adverse Endocrine and Metabolic Effects of Psychotropic Drugs. CNS Drugs 2009, 23, 1003-1021. [CrossRef]

148. Kane, J.M. Pharmacologic Treatment of Schizophrenia. Biol. Psychiatry 1999, 46, 1396-1408. [CrossRef]

149. Bressington, D.T.; Mui, J.; Cheung, E.F.C.; Petch, J.; Clark, A.B.; Gray, R. The Prevalence of Metabolic Syndrome amongst Patients with Severe Mental Illness in the Community in Hong Kong-A Cross Sectional Study. BMC Psychiatry 2013, 13, 87. [CrossRef]

150. Pirillo, A.; Catapano, A.L. Berberine, a Plant Alkaloid with Lipid- and Glucose-Lowering Properties: From in Vitro Evidence to Clinical Studies. Atherosclerosis 2015, 243, 449-461. [CrossRef]

151. Lan, J.; Zhao, Y.; Dong, F.; Yan, Z.; Zheng, W.; Fan, J.; Sun, G. Meta-Analysis of the Effect and Safety of Berberine in the Treatment of Type 2 Diabetes Mellitus, Hyperlipemia and Hypertension. J. Ethnopharmacol. 2015, 161, 69-81. [CrossRef]

152. Hu, Y.; Young, A.J.; Ehli, E.A.; Nowotny, D.; Davies, P.S.; Droke, E.A.; Soundy, T.J.; Davies, G.E. Metformin and Berberine Prevent Olanzapine-Induced Weight Gain in Rats. PLOS ONE 2014, 9, e93310. [CrossRef] [PubMed]

153. Peng, W.-H.; Wu, C.-R.; Chen, C.-S.; Chen, C.-F.; Leu, Z.-C.; Hsieh, M.-T. Anxiolytic Effect of Berberine on Exploratory Activity of the Mouse in Two Experimental Anxiety Models: Interaction with Drugs Acting at 5-HT Receptors. Life Sci. 2004, 75, $2451-2462$. [CrossRef] [PubMed]

154. Kawano, M.; Takagi, R.; Kaneko, A.; Matsushita, S. Berberine Is a Dopamine D1- and D2-like Receptor Antagonist and Ameliorates Experimentally Induced Colitis by Suppressing Innate and Adaptive Immune Responses. J. Neuroimmunol. 2015, 289 , 43-55. [CrossRef]

155. Salehi, S.; Filtz, T.M. Berberine Possesses Muscarinic Agonist-like Properties in Cultured Rodent Cardiomyocytes. Pharmacol. Res. 2011, 63, 335-340. [CrossRef] [PubMed]

156. Wang, H.-H.; Cai, M.; Wang, H.-N.; Chen, Y.-C.; Zhang, R.-G.; Wang, Y.; McAlonan, G.M.; Bai, Y.-H.; Wu, W.-J.; Guo, L.; et al. An Assessor-Blinded, Randomized Comparison of Efficacy and Tolerability of Switching from Olanzapine to Ziprasidone and the Combination of Both in Schizophrenia Spectrum Disorders. J. Psychiatr. Res. 2017, 85, 59-65. [CrossRef]

157. Haffner, S.M.; Miettinen, H.; Stern, M.P. The Homeostasis Model in the San Antonio Heart Study. Diabetes Care 1997, 20, 1087-1092. [CrossRef]

158. Gharabawi, G.M.; Bossie, C.A.; Lasser, R.A.; Turkoz, I.; Rodriguez, S.; Chouinard, G. Abnormal Involuntary Movement Scale (AIMS) and Extrapyramidal Symptom Rating Scale (ESRS): Cross-Scale Comparison in Assessing Tardive Dyskinesia. Schizophr. Res. 2005, 77, 119-128. [CrossRef]

159. Kysenius, K.; Brunello, C.A.; Huttunen, H.J. Mitochondria and NMDA Receptor-Dependent Toxicity of Berberine Sensitizes Neurons to Glutamate and Rotenone Injury. PLOS ONE 2014, 9, e107129. [CrossRef]

160. Kulkarni, S.K.; Dhir, A. On the Mechanism of Antidepressant-like Action of Berberine Chloride. Eur. J. Pharmacol. 2008, 589, 163-172. [CrossRef] 
161. Lee, B.; Sur, B.; Yeom, M.; Shim, I.; Lee, H.; Hahm, D.-H. Effect of Berberine on Depression- and Anxiety-like Behaviors and Activation of the Noradrenergic System Induced by Development of Morphine Dependence in Rats. Korean J. Physiol. Pharmacol. 2012, 16, 379-386. [CrossRef]

162. Kong, L.D.; Cheng, C.H.; Tan, R.X. Monoamine Oxidase Inhibitors from Rhizoma of Coptis Chinensis. Planta Med. 2001, 67, 74-76. [CrossRef] [PubMed]

163. Peng, W.-H.; Lo, K.-L.; Lee, Y.-H.; Hung, T.-H.; Lin, Y.-C. Berberine Produces Antidepressant-like Effects in the Forced Swim Test and in the Tail Suspension Test in Mice. Life Sci. 2007, 81, 933-938. [CrossRef] [PubMed]

164. Fan, J.; Zhang, K.; Jin, Y.; Li, B.; Gao, S.; Zhu, J.; Cui, R. Pharmacological Effects of Berberine on Mood Disorders. J. Cell. Mol. Med. 2019, 23, 21-28. [CrossRef] [PubMed]

165. Lin, X.; Zhang, N. Berberine: Pathways to Protect Neurons. Phytother. Res. 2018, 32, 1501-1510. [CrossRef] [PubMed]

166. Singh, N.; Sharma, B. Toxicological Effects of Berberine and Sanguinarine. Front. Mol. Biosci. 2018, 5. [CrossRef] [PubMed]

167. Ahmed, T.; Gilani, A.-H.; Abdollahi, M.; Daglia, M.; Nabavi, S.F.; Nabavi, S.M. Berberine and Neurodegeneration: A Review of Literature. Pharmacol. Rep. 2015, 67, 970-979. [CrossRef]

168. Kulkarni, S.K.; Dhir, A. Berberine: A Plant Alkaloid with Therapeutic Potential for Central Nervous System Disorders. Phytother. Res. 2010, 24, 317-324. [CrossRef]

169. Imenshahidi, M.; Hosseinzadeh, H. Berberis Vulgaris and Berberine: An Update Review. Phytother. Res. 2016, 30, 1745-1764. [CrossRef]

170. Lee, B.; Yang, C.H.; Hahm, D.-H.; Choe, E.S.; Lee, H.-J.; Pyun, K.-H.; Shim, I. Inhibitory Effects of Coptidis Rhizoma and Berberine on Cocaine-Induced Sensitization. Evid.-Based Complementary Altern. Med. 2009, 6, 85-90. [CrossRef] 